\title{
Article \\ Hydrochemical Characteristics of Thermal Water Reservoir in Lądek-Zdrój in Light of Research into the Borehole LZT-1-The Deepest Borehole in the Sudetes (SW Poland)
}

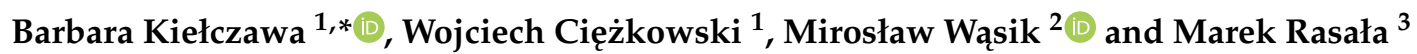 \\ 1 Department of Mining, Faculty of Geoengineering, Mining and Geology, Wroclaw University of Science and \\ Technology, 50-370 Wrocław, Poland; wojciech.ciezkowski@pwr.edu.pl \\ 2 Institute of Geological Science, Faculty of Earth Science and Environmental Management, \\ Wroclaw University, 50-137 Wrocław, Poland; miroslaw.wasik@uwr.edu.pl \\ 3 Institute of Geology, Faculty of Geographic and Geological Science, Adam Mickiewicz University, \\ 61-712 Poznań, Poland; mrasala@amu.edu.pl \\ * Correspondence: barbara.kielczawa@pwr.edu.pl
}

check for updates

Citation: Kiełczawa, B.; Ciężkowski, W.; Wąsik, M.; Rasała, M. Hydrochemical Characteristics of Thermal Water Reservoir in Ladek-Zdrój in Light of Research into the Borehole LZT-1-The Deepest Borehole in the Sudetes (SW Poland). Energies 2021, 14, 1009. https:// doi.org/10.3390/en14041009

Received: 20 December 2020

Accepted: 9 February 2021

Published: 15 February 2021

Publisher's Note: MDPI stays neutral with regard to jurisdictional claims in published maps and institutional affiliations.

Copyright: (c) 2021 by the authors. Licensee MDPI, Basel, Switzerland. This article is an open access article distributed under the terms and conditions of the Creative Commons Attribution (CC BY) license (https:// creativecommons.org/licenses/by/ $4.0 /)$.
Abstract: Lądek-Zdrój is situated within the tectonic unit of the Lądek-Śnieżnik metamorphic complex. Thermal water is captured by five springs and borehole L-2. These waters are characterized by TDS content in the range of $160-230 \mathrm{mg} / \mathrm{L}$ and predominance of $\mathrm{HCO}_{3}{ }^{-}\left(15-100 \%\right.$ meq), $\mathrm{SO}_{4}{ }^{2+}$ (10-36\% meq), and $\mathrm{Na}^{+}$(57-91\% meq) ions. Increased concentrations of radon, hydrogen sulfide, and fluoride ions (7-13 mg/L) determine the medicinal properties of these waters, classified as thermal waters of $\mathrm{Na}-\mathrm{HCO}_{3}-\left(\mathrm{SO}_{4}\right), \mathrm{F}^{-}, \mathrm{H}_{2} \mathrm{~S}$, Rn type, with temperatures of 18 to $30{ }^{\circ} \mathrm{C}$ and 41 to $45^{\circ} \mathrm{C}$ in springs and in the L-2 borehole, respectively. At the turn of 2018 and 2019, a new borehole LZT-1 was drilled in the area of Ladek-Zdrój. It captured thermal waters with a temperature of $37.4^{\circ} \mathrm{C}$ at the outflow. The water temperature at the bottom of the heated borehole reached about $59{ }^{\circ} \mathrm{C}$. The lithology of rocks found in the recharged areas implied that the $\mathrm{Ca}^{2+}$ ions present in the studied waters originated from pyroxenes, amphiboles, calcite, calcium plagioclases, and fluorite. As for $\mathrm{Na}^{+}$and $\mathrm{K}^{+}$ions, they originate from sodium plagioclases, microcline, and orthoclase. The probable deposit temperature of waters from this borehole was estimated with the use of chemical geothermometers, as ranging from about $87^{\circ} \mathrm{C}$ to $97^{\circ} \mathrm{C}$.

Keywords: geothermal water; medicinal water; hydrochemistry; geothermometers; crystalline massif; Lądek-Zdrój; Poland

\section{Introduction}

The Sudetes form the northern part of the Bohemian Massif, a Variscan geological unit rejuvenated in the Alpine orogeny, is cut by a system of faults into numerous smaller blocks and plates. Deep fractures fostered the intensive volcanism and the influx of $\mathrm{CO}_{2}$ saturating groundwaters that occurs in this area [1,2].

In the Sudetes, in the territory of both Poland and the Czech Republic, $\mathrm{CO}_{2}$-rich waters and naturally carbonated waters are accompanied by thermal waters. Their most important deposits include ones (starting from the west) in Janské Lázně, Jelenia GóraCieplice, Lądek-Zdrój, and Bludov and Velké Losiny [3-5].

The geothermal systems are wide spread and were studied by many scientists [6-10].

The low-enthalpy geothermal waters attract attention due to their direct usage for geothermal and balneotherapeutical purposes. To date, the chemistry of geothermal waters was studied by many scientists, e.g., [5,10-16] et al. The application of solute geothermometers to estimation temperature of geothermal systems was discussed in detail by Fournier i Trusdel [17], Fournier [11,18], Arnórsson [19,20], Arnórsson et al. [10], Giggenbach [21], Cave and Clarke [22], Pfeiffer et al. [23], as well as Pang and Red [24] et al. 
Sodium bicarbonate thermal waters containing fluoride, radon, and hydrogen sulfide are known in Europe in Czech Republik (Vělké Losiny, Janské Láznĕ, Bludov, Teplice, Ústí nad Labem) [25,26], SW Poland (Turów, Jelenia Góra-Cieplice) [5], Austria (Central Alps-Bad Gastein, Hintertux) [27], Switzerland (e.g., Lavey-les-Bains, Saint-Gervais-lesBains) [28], and France (e.g., Vernet, Molitg, La Preste, Ax-Les-Thermes), [29]. Springs with waters of similar type are localized in Russia (Talskije and Kuldur springs) [30], India [31], as well as in New Zealand (Lake Sumner) [30]. In Japan, Yaguchi et al. [32] studied numerous non-volcanic hot springs. However, despite the similarities in the chemical type, the differences among these waters are in their outflow temperature and mineralization.

Lądek-Zdrój is one of the best known health resorts in Poland. Visitors have been coming here for curative purposes for centuries. At the turn of 2018-2019, the deepest $(2.5 \mathrm{~km})$ exploratory borehole in the Polish Sudetes was drilled here to access thermal waters. The drilling offered a unique opportunity for the study of the geothermal system in this part of Poland, and the chemistry of deep circulation geothermal waters as well as water-rock processes determining the composition of water. The aim of this paper was to present the newest research into deep circulation waters against the background of waters extracted from intakes in the Lądek-Zdrój health resort.

\subsection{Previous Research into the Chemistry of Ladek Waters}

The medicinal thermal waters of Ladek-Zdrój were studied for many years (the definition of medicinal water is explained in the section "Materials and Methods"). The research conducted before World War II is of historic character. It did not provide a broad description of these waters, focusing mostly on their genesis and the relationship between springs location and the course of faults. The first works published after World War II comprised the results of physicochemical analyses of waters from particular intakes and confirmed results of physicochemical analyses obtained before 1945 [33-35]. General information on the hydrochemistry of springs can be found in works by Gierwielaniec [36,37], Fistek [38], and Fistek and Szarszewska [39]. They considered the waters of Lądek-Zdrój as the last manifestation of tertiary magmatic activity or infiltration origin [36,37] and associated their occurrence with the faults of the NW-SE course. Comprehensive hydrogeological descriptions of these springs were provided by Gierwielaniec [36,37], Ciężkowski and Ciężkowski [40], and Ciężkowski [5,41,42]. Detailed information about this deposit, its particular intakes and the physical and chemical properties of these waters was provided by Ciężkowski [43]. Hydrochemical characteristics of Lądek waters were also presented by Kiełczawa [44]. The location of recharge areas of the discussed deposit was the subject of work by Zuber et al. [45] and Ciężkowski et al. [46]. They estimated the location of these areas based on the stable isotope composition of waters. Dowgiałło [4], Dowgiałło et al. [47], Porowski [48], and Porowski and Dowgiałło [49] presented the results of deposit temperature estimation conducted with the use of geothermometers (see Section 3.1). At the same time, Leśniak [50], Leśniak and Nowak [51], and Dobrzyński and Leśniak [52] estimated the probable deposit temperatures $\left(80 \pm 5^{\circ} \mathrm{C}\right)$ using an analysis of saturation of Lacdek waters with a selected rock-forming minerals. Analyses of radon activity concentration in the waters of the discussed deposit and origin of this gas were the subject of work by Ciężkowski et al. [53], Przylibski and Żebrowski [54], and Przylibski e.g., [55,56]. A lot of information about the genesis of Ladek waters was provided by the results of isotopic research and studies of noble gases $[5,44]$. Furthermore, based on these results, the location of the recharge area of the Ladek reservoir was confirmed.

\subsection{Geological Structure of the Study Area}

Medicinal thermal waters of Lądek-Zdrój occur within the Lądek-Śnieżnik metamorphic complex - the easternmost tectonic unit of the Central Sudetes. It is bound by the Ramzová overthrust to the east. Its northern border is made up of the Upper-Carboniferous Kłodzko-Złoty Stok intrusion, and it borders on the Upper Nysa Trough to the west. The Lądek-Śnieżnik metamorphic complex is part of a larger tectonic unit known as the 
Orlica-Śnieżnik Dome [57]. It is built of strongly metamorphosed rocks forming three Proterozoic-Palaeozoic complexes. These are:

- $\quad$ schists of the so-called Stronie series (mica schists with paragneiss, quartzite, marble, erlan and amphibolite insertions),

- Gierałtów gneisses (with amphibolite, eclogite, and granulite insertions),

- Śnieżnik gneisses.

These series were formed as a result of polymorphic and polycyclic evolution of a supracrustal series.

During the Carboniferous, granitoid intrusions and the related vein rocks were formed within the Ladek-Śnieżnik metamorphic complex [57,58].

The tectonic structure of the Ladek-Zdrój area contains fan-like overlapping fold elements converging westwards [59]. The largest of them are:

- the Radochów anticlinorium (built of Gierałtów gneisses),

- $\quad$ the Ladek synclinorium (formed within mica schists of the Stronie series),

- the Gierałtów anticlinorium (formed by Gierałtów gneisses).

These tectonic elements are cut with transverse and longitudinal faults shown in Figure 1A,B. The course of the transverse faults is consistent with the so-called Sudetic direction (NW-SE).

In the Neogene, these dislocations became the migration paths of basalt lavas [60].
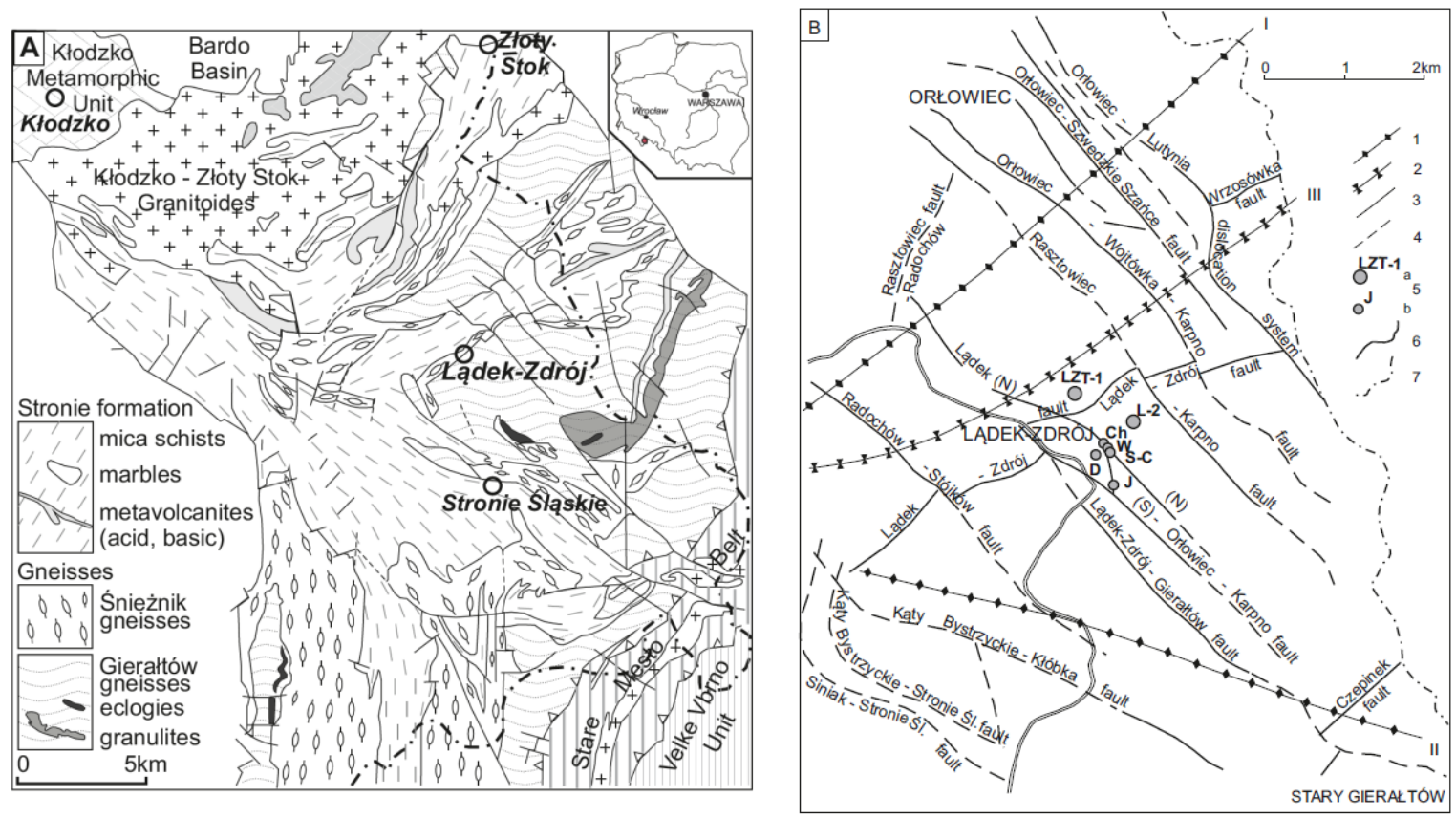

Figure 1. (A) The geologic map (based on [61]); (B) The tectonic map of the Ladek-Zdrój area (based on [58]). Key: 1—anticlinal axis: I-Radochów, II—Gierałtów; 2-synclinal axis: III-Lądek; 3-documented faults; 4-presumed faults; 5-thermal water intakes: a-boreholes, b-springs; 6-river; 7-Polish border with Czech Republic.

The presence and the strike of these dislocations were verified by geophysical research [62]. The Quaternary in the examined area is represented mainly by alluvium, weathered rock sediments and slope debris.

\subsection{Conditions of Groundwater Occurrence}

In the area of the medicinal water deposit of Ladek-Zdrój, two aquifer horizons could be identified-a Quaternary and a Palaeozoic-Proterozoic one. The Quaternary horizon is made up of waters flowing through Holocene sandy deposits filling valley floors and through gravels in river terraces. 
The known Ladek waters flow out of gneissic rocks lying on the north-western periphery of the Gierałtów anticlinorium. Several hundred metres NW of the resort centre, along the Ladek-Zdrój fault identified by Gierwielaniec [37], this structure borders on the Ladek synclinorium built of poorly permeable schistose rocks of the Stronie series. The location of all intakes can be seen in Figure 1B.

The dominant role in this area is played by groundwaters associated with Proterozoic and Palaeozoic crystalline rocks and their weathered rock covers. This horizon comprises three water circulation systems. The first one (I zone) contains contemporary fissure waters occurring in weathered rock covers, as shown in Figure 2. It reaches a depth of $10 \mathrm{~m}$, and locally $-30 \mathrm{~m}$, and is very abundant. Another system is made up of waters accumulating within a densely fractured crystalline massif to the depth of 2000-2500 m (II zone). The capacity of this system is low, and the age of its waters is from hundreds to thousands of years. The third horizon (III zone) is a system of groundwaters circulating deep (at the depths of over 2-2.5 km) in regional-scale dislocation zones $[63,64]$.

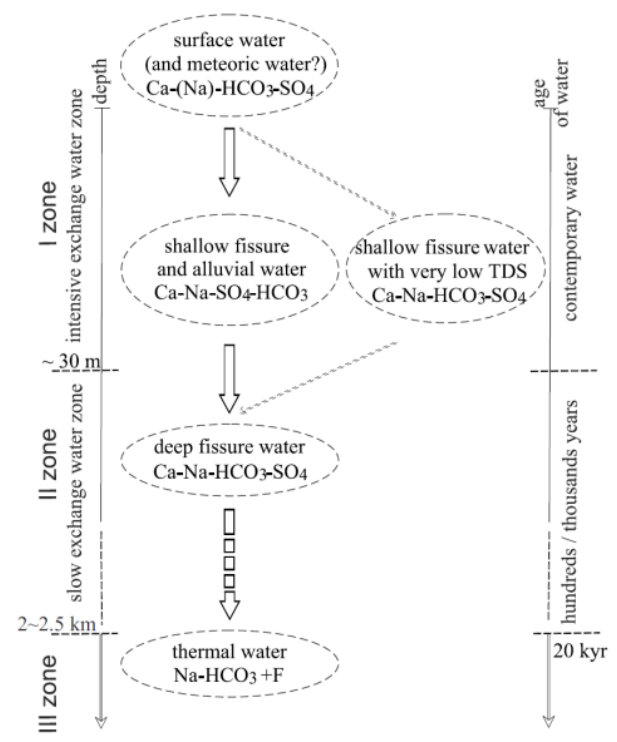

Figure 2. Diagram showing water-content zonation and the evolution of the chemical composition of groundwaters in a depth profile of the Śnieżnik massif (based on [63]).

While analyzing the chemical composition of plain groundwaters in the LadekŚnieżnik metamorphic complex as compared to the physicochemical properties of thermal waters, one can create a generalized diagram illustrating their evolution and vertical hydrochemical zonation, visualized in Figure 2. As the diagram shows, poorly mineralized (TDS-Total Dissolved Solids $<100 \mathrm{mg} / \mathrm{L}$ ) surface waters of $\mathrm{Ca}(-\mathrm{Na})-\mathrm{HCO}_{3}-\mathrm{SO}_{4}$ type infiltrate deep into the zone of weathering-related fissuring. While circulating within the rock medium, they slightly increase their TDS content, occasionally reaching $1000 \mathrm{mg} / \mathrm{L}$. At the same time, the ratios of major ions change in favor of sulfate and sodium ions. As a result of intensive water exchange, $\mathrm{Ca}-\mathrm{Na}-\mathrm{SO}_{4}-\mathrm{HCO}_{3}$ type waters are formed. This zone also contains waters with slightly modified, in comparison with surface waters, ion ratios, i.e., $\mathrm{Ca}-\mathrm{Na}-\mathrm{HCO}_{3}-\mathrm{SO}_{4}$ type waters (Figure 2). Waters of this type are also observed deeper in the hydrochemical profile, in zone II of slower water exchange. Their TDS at the depth of c. $600 \mathrm{~m}$, reaches the value of c. $150 \mathrm{mg} / \mathrm{L}$.

When moving inside the crystalline massif (zone III), these waters get richer in sodium and fluoride ions. As a result, at the depth of about $2500 \mathrm{~m}$ within the Ladek-Śnieżnik metamorphic complex, low-TDS $\mathrm{HCO}_{3}$-Na fluoride geothermal waters with an estimated retention time of c. 20,000 years are formed [41].

Thermal medicinal waters of Lądek-Zdrój, flowing out at the height of c. $450 \mathrm{~m}$, are extracted from five springs (Wojciech, Jerzy, Dabrówka, Skłodowska-Curie, Chrobry) [39,40]. 
Natural outflows are observed along longitudinal dislocations (NW-SE). The waters of this circulation system are also captured by 700 m-deep borehole L-2, while borehole L-1 captures plain waters $[43,65]$.

The springs are encased in wells or tanks, and the L-2 borehole is closed with an extraction wellhead.

The discharge of the springs typically ranges from $0.7 \mathrm{~m}^{3} / \mathrm{h}$ (Dabrówka) to $3.45 \mathrm{~m}^{3} / \mathrm{h}$ (Skłodowska-Curie). The discharge of the Jerzy spring is exceptionally high, reaching c. $13.5 \mathrm{~m}^{3} / \mathrm{h}$. A slightly higher discharge, i.e., $15.3 \mathrm{~m}^{3} / \mathrm{h}$ is observed in the free-flowing borehole L-2 [66]. The springs of Lądek-Zdrój are categorized as perennial springs, but their deposit regime is very vulnerable [42,67]. Their hydrodynamic equilibrium conditions were disturbed in the 1970s by drilling two boreholes L-1 and L-2. Hydrodynamic tests carried out in 1973 and the subsequent exploitation (in 1976-1978) of the L-2 borehole resulted in a reduction in thermal spring discharge and the lowering of the plain water table in borehole L-1 [43].

Research conducted by Liber [66-69] confirmed the existence of strong hydraulic connections between particular thermal water intakes, especially between the springs of Wojciech and Skłodowska-Curie. Monitoring the intensity of water outflow from springs and exploitation of the L-2 borehole as a flowing well enabled the development of stable deposit management conditions. Ciężkowski [42,43] distinguished several chemical types of fissure waters in the area of Lądek-Zdrój. These are shallow and deep-circulation system waters whose hydrochemical background are $\mathrm{Ca}-\mathrm{Na}-\mathrm{SO}_{4}-\mathrm{HCO}_{3}$ type waters of zone I and II. Deep-circulation $\mathrm{Na}_{-} \mathrm{HCO}_{3}$, F-type thermal waters of zone III inflowing through fracture and fissure systems are the reason for a local hydrochemical anomaly occurring in the resort area, noted in Figure 3.

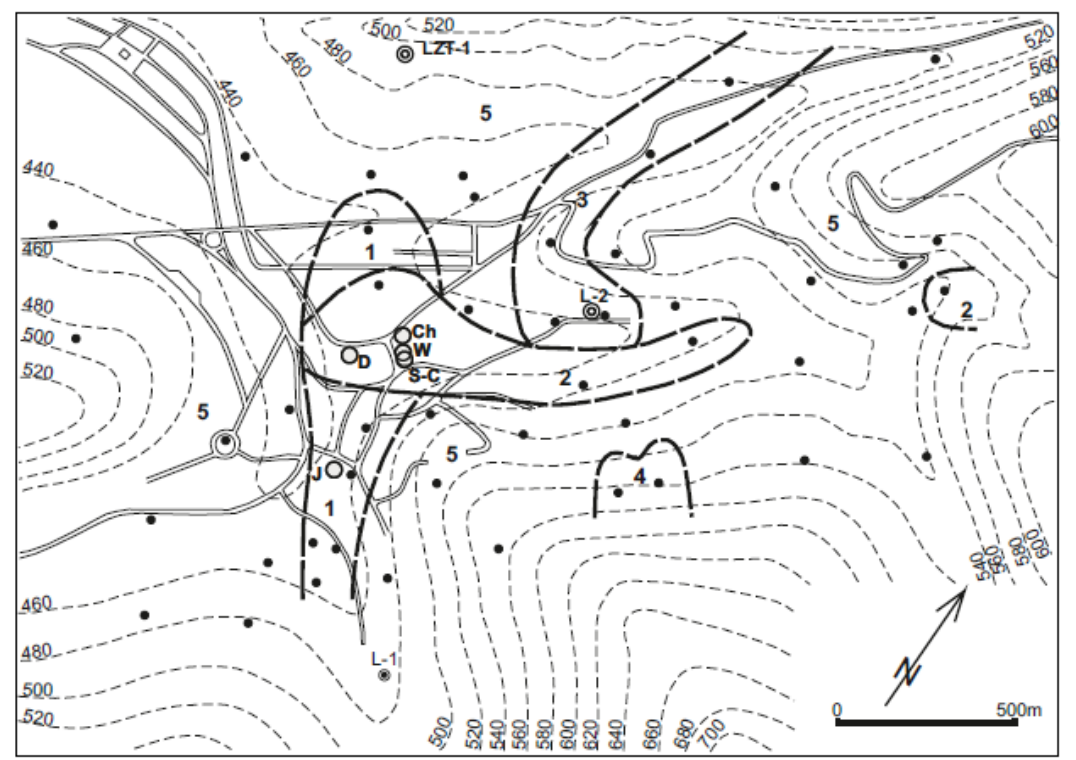

Figure 3. The hydrochemical anomaly of the Ladek-Zdrój area (based on [5]). Key-chemical types of waters: $1-\mathrm{Na}-\mathrm{Ca}-\mathrm{HCO}_{3}-\mathrm{SO}_{4}, 2-\mathrm{Na}-\mathrm{HCO}_{3}-\mathrm{SO}_{4}, 3-\mathrm{Ca}-\mathrm{Na}-\mathrm{HCO}_{3}-\mathrm{SO}_{4}, 4-\mathrm{Ca}-\mathrm{Na}-\mathrm{HCO}_{3}-\mathrm{SO}_{4}$, and 5-Ca-Na-SO $\mathrm{S}_{4}-\mathrm{HCO}_{3}$; spring designation: J-Jerzy, S-C—Skłodowska-Curie, W-Wojciech, Ch—Chrobry, and D—Dabrówka; boreholes: L-2, LZT-1; black points—shallow boreholes; dashed lines-borders between chemical types of waters determined on the basis of 50 shallow boreholes.

Water temperatures at the outflow from particular springs range from about $18^{\circ} \mathrm{C}$ to $30^{\circ} \mathrm{C}$, and from $41^{\circ} \mathrm{C}$ to $45^{\circ} \mathrm{C}$ in the L-2 borehole $[43,44]$. These temperatures varied by $2{ }^{\circ} \mathrm{C}$ to a maximum of $4{ }^{\circ} \mathrm{C}$ in all intakes. The results of research into stable isotopes of oxygen and hydrogen demonstrate that the Ladek reservoir is recharged in areas lying above a height of $700 \mathrm{~m}$. This was also confirmed by results of noble gas analyses. These 
areas lie about $10 \mathrm{~km}$ SE of the health resort, within the Bialskie Mountains and the southern part of the Złote Mountains [5,45,46].

The age of the studied waters was estimated to be about 9000 years.

About a dozen kilometres SE of Ladek-Zdrój, two occurrences of thermal waters characterized by physicochemical properties comparable to those of Ladek waters were identified in the crystalline rocks of the Moravian-Silesian structure. In Bludov, waters extracted from the depth of 500-600 m were characterized by temperatures of $24-25^{\circ} \mathrm{C}$, TDS content of $400 \mathrm{mg} / \mathrm{L}$, and the $\mathrm{Na}-\mathrm{Ca}-\mathrm{Mg}_{-} \mathrm{SO}_{4}-\mathrm{Cl}$ type, with an increased $\mathrm{F}^{-}$ion content (6.8-7.5 mg/L). In Velké Losiny, there are three springs and several boreholes, the deepest of which reaches $1000 \mathrm{~m}$ below ground level. Their poorly mineralised (TDS content of $\mathrm{c}$. $200 \mathrm{mg} / \mathrm{L}$ ) thermal waters (temperature of $25-35^{\circ} \mathrm{C}$ ) were classified as $\mathrm{Na}-\mathrm{HCO}_{3}-\mathrm{SO}_{4}-$ type, fluoride $\left(\mathrm{F}^{-}-4-5 \mathrm{mg} / \mathrm{L}\right)$, sulfide $\left(\mathrm{H}_{2} \mathrm{~S}-1-4.6 \mathrm{mg} / \mathrm{L}\right)$ waters $[1,2,70,71]$.

\section{Materials and Methods}

A large data set of physicochemical parameters was collected due to the long-term (from 1965 to 2018) monitoring. Monitoring measurements during drilling were carried out by geological survey of the Lądek-Zdrój health resort. During the pumping test, the water table in the pumping and in observation wells was measured regularly (once a day). The response to pumping in L-2 well was also monitored by pressure measurements at the wellhead.

These waters chemistry data were assembled and updated from published reports and archival records, as well as the results of sampling the LZT-1 borehole. During field work, two samples of geothermal waters from the depths of 1305-2500 m were collected. Chemical analyses were made in an accredited laboratory [72]. Results of these analyses were examined by calculating the ionic charge balance and one of the most accurate was selected.

The collected data were used to determine hydrochemical characteristic of deep circulation waters and the origin of the principal chemical components as well as the relationships between ion concentrations.

Kurlov's formula was used to summarize the dominant water composition. It took the following form [73]:

$$
S_{p} G M \frac{\text { anions }}{\text { cations }} T
$$

where $S p$ —specific components/elements [mg/L], G—dissolved gases [g/L], M-TDS $[\mathrm{g} / \mathrm{L}]$, anions and cations-written in descending sequence as $\% \mathrm{meq} / \mathrm{L}$, and $\mathrm{T}$-water temperature $\left[{ }^{\circ} \mathrm{C}\right]$.

It is a useful method for chemical characterization of the water [72]. Chemical composition is expressed by the percentage content of major anions and cations in the numerator and denominator, respectively. In determining the water type, only those constituents are considered which amount to more than $20 \% \mathrm{meq} / \mathrm{L}$ of the total anions or cations. Specific elements, dissolved gases and temperature of water are additional information for determination of medicinal water.

It should be noted that medicinal water is defined as groundwater with natural fluctuations of physicochemical parameters, with no microbiological and chemical contamination. The water is considered medicinal/therapeutic if it contains at least a minimum amount of one of the specific components (pharmacologically active). The components are determined by Government standards and are listed in Table 1. Polish Government regulations also classify waters by temperature as cold-if the water flows from earth at a temperature under $20^{\circ} \mathrm{C}$ and as thermal water, when the temperature of water is a minimum of $20{ }^{\circ} \mathrm{C}$ or hotter. Thermal and cold waters containing pharmacologically active compounds can be classified as medicinal as well $[74,75]$. 
Table 1. Minimal concentrations of specific components and temperature of water and TDS for medicinal water classification (based on [74]).

\begin{tabular}{|c|c|c|}
\hline \multicolumn{3}{|c|}{ Parameters } \\
\hline Temperature $\left({ }^{\circ} \mathrm{C}\right)$ & Concentration of Specific Components (Name of Medicinal Water) & TDS-Total Dissolved Solids (g/L) \\
\hline$\geq 20$ (thermal water) & 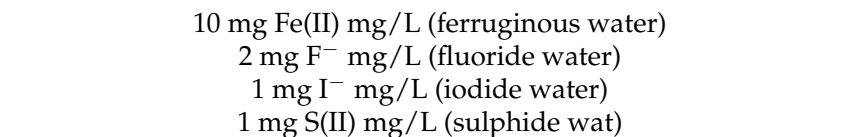 & $\geq 1$ (mineral water) \\
\hline$<20$ (cold water) & $\begin{array}{c}70 \mathrm{mg} \mathrm{H}_{2} \mathrm{SiO}_{3} \mathrm{mg} / \mathrm{L} \text { (silica water) } \\
74 \mathrm{~Bq} \mathrm{Rn}_{\mathrm{L}} \mathrm{L} \text { (radon water) } \\
250 \mathrm{mg} \text { free } \mathrm{CO}_{2} \mathrm{mg} / \mathrm{L} \text { (carbonated water) } \\
1000 \mathrm{mg} \text { free } \mathrm{CO}_{2} \mathrm{mg} / \mathrm{L}\left(\mathrm{CO}_{2} \text {-rich water, carbonated water) }\right.\end{array}$ & $<1$ (lightly mineralized water) \\
\hline
\end{tabular}

Based on an analysis of physicochemical properties of the studied waters from the new borehole LZT- 1 and on the available literature data, an attempt was made to estimate the reservoir temperature with the use of the chemical geothermometers listed in Table 2. It must be noted that the basic assumptions of using such geothermometers are the presumed equilibrium state of a solution (of geothermal water), with the rock medium within the aquifer, and the fact that a disturbance of this equilibrium on the water flow path is insignificant. Changes in the chemical composition of thermal waters resulting from their mixing with cool waters from shallow circulation systems might also affect the values of the estimated temperatures $[19,76-78]$.

Table 2. Expressions for different geothermometers.

\begin{tabular}{ccc}
\hline Geothermometer & $T=\frac{1309}{5.19-\log S_{2} O_{2(a q)}}-273.15$ & References \\
\hline $\mathrm{Q}$ & $T=\frac{1032}{4.69-\operatorname{logSiO_{2(aq)}}-273.15}$ \\
$\mathrm{Ch}_{1}$ & $T=\frac{1112}{4.91-\log S i O_{2(a q)}}-273.15$ \\
$\mathrm{Ch}_{2}$ & $T=\frac{933}{0.993+\log \left(\frac{\mathrm{Na}}{K}\right)}-273.15$
\end{tabular}

Q-SiO 2 (aq) concentration in $\mathrm{mg} / \mathrm{L} ; \mathrm{Ch}_{1}-\mathrm{SiO}_{2(a q)}$ concentrations in $\mathrm{mg} / \mathrm{L} ; \mathrm{Ch}_{2}$ - $\mathrm{SiO}_{2(a q)}$ concentration in $\mathrm{mg} / \mathrm{L}$; $\mathrm{Na}-\mathrm{K}-\mathrm{Na}$ and $\mathrm{K}$ concentrations in $\mathrm{mol} / \mathrm{kgH}_{2} \mathrm{O}$; and $\mathrm{Na}-\mathrm{K}-\mathrm{Ca}-\mathrm{Na}, \mathrm{K}$ and $\mathrm{Ca}$ concentrations in $\mathrm{mol} / \mathrm{kgH}_{2} \mathrm{O}$.

The saturation state of the geothermal waters with the primary and secondary minerals were conducted using the PhreeqIC software and Wateq4f database. The elaboration on the chemical parameters of waters from particular intakes and the plots were carried out using the Aquchem app.

\section{Results and Discussion}

\subsection{Reults of the New LZT-1 Drilling}

Between October 2018 and June 2019, a new 2.5 kilometre-deep borehole LZT-1 was drilled NW of the existing thermal water intakes. The well was completed as is, with surface casing, intermediate casing and liner. The casing was set from the ground level to the depth of $1305 \mathrm{~m}$. The deeper that the borehole stood open. Five main geological units were defined from the surface to $4 \mathrm{~m}$ of depth, a weathering rocks; at the depth of 4-231.5 m-mica schists; from 231.5 to $236 \mathrm{~m}$-crystalline limestones; from 236 to $409 \mathrm{~m}$ quartz schists and from 409 to $2500 \mathrm{~m}$-gneisses [72].

During hydrodynamic tests in LZT-1, waters flowing to the hole from a series of fractured gneisses (from the depths of 1305-2500 m) were sampled. However, given the 
drilling fluid escape zones, the main water inflow zone should be located at a depth of 1460-1795 m. Potentially, one can obtain the discharge of c. $60 \mathrm{~m}^{3} / \mathrm{h}$ from the borehole, with a depression of c. $70 \mathrm{~m} \mathrm{[72].}$

In the LZT-1 borehole, water temperature at the outflow, with a discharge rate of $10 \mathrm{~m}^{3} / \mathrm{h}$ was $37.4^{\circ} \mathrm{C}$, while the rock mass temperature at the bottom of the heated borehole was $58.9^{\circ} \mathrm{C}$. Based on the results of analyses of their physicochemical properties, the studied waters could be classified as thermal fluoride and radon waters. They contain about $190 \mathrm{mg} / \mathrm{L}$ of total dissolved solids, which is not different from the TDS content in waters from the spa intakes (Table 3). The major-ion composition was dominated by $\mathrm{HCO}_{3}{ }^{-}\left(57 \%\right.$ meq) and $\mathrm{SO}_{4}{ }^{2-}$ anions $\left(20 \%\right.$ meq). The most numerous cations were $\mathrm{Na}^{+}$ ions ( $87 \%$ meq) [79]. Table 3 shows water composition from the LZT-1 borehole. What is noteworthy is a considerable proportion of fluoride ions reaching $11.1 \mathrm{mg} / \mathrm{L}$. The amount of $\mathrm{H}_{2} \mathrm{~S}$ in the waters from LZT-1 borehole was $0.7 \mathrm{mg} / \mathrm{L}$ [72]. Moreover, the studied waters were characterized by an increased activity concentration of radon ${ }^{222} \mathrm{Rn}$, which was $93.9 \pm 4.1 \mathrm{~Bq} / \mathrm{L}$ (Table 3). The low concentration of $\mathrm{Mg}^{2+}(<1.2 \mathrm{mg} / \mathrm{L})$ was probably due to low solubility of magnesium silicates and carbonates at high $\mathrm{pH}[6]$.

Table 3. Principal components and physical parameters of the geothermal water from LZT-1 (2019) (based on [72]).

\begin{tabular}{cccccccccccccccc}
\hline $\mathbf{p H}$ & $\mathbf{N a}^{+}$ & $\mathrm{K}^{+}$ & $\mathbf{M g}^{2+}$ & $\mathbf{C a}^{2+}$ & $\mathbf{F e}^{2+}$ & $\mathbf{N H}_{4}$ & $\mathbf{H C O}_{3}{ }^{-}$ & $\mathbf{F}^{-}$ & $\mathrm{Cl}^{-}$ & $\mathbf{S O}_{4}{ }^{2}$ & $\mathbf{B a}$ & $\mathbf{S i O}_{2}$ & $\mathrm{TDS}$ & $\mathbf{E C}$ & $\mathbf{R n}$ \\
\hline- & & & & & & & $\mathbf{( m g} / \mathrm{L})$ & & & & & & $(\mathbf{m S} / \mathbf{c m})$ & $\mathbf{( B q} / \mathbf{L})$ \\
\hline 9.6 & 49.6 & 2.51 & $<1.2$ & 4.01 & 0.148 & 0.117 & 97.6 & 11.1 & $<5$ & 20 & 0.041 & 35.7 & 189 & 0.305 & $93.9 \pm 4.1$ \\
\hline
\end{tabular}

Chemically, thermal waters from the deep borehole LZT- 1 are dominated by bicarbon-

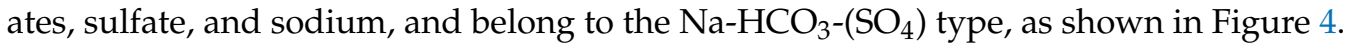

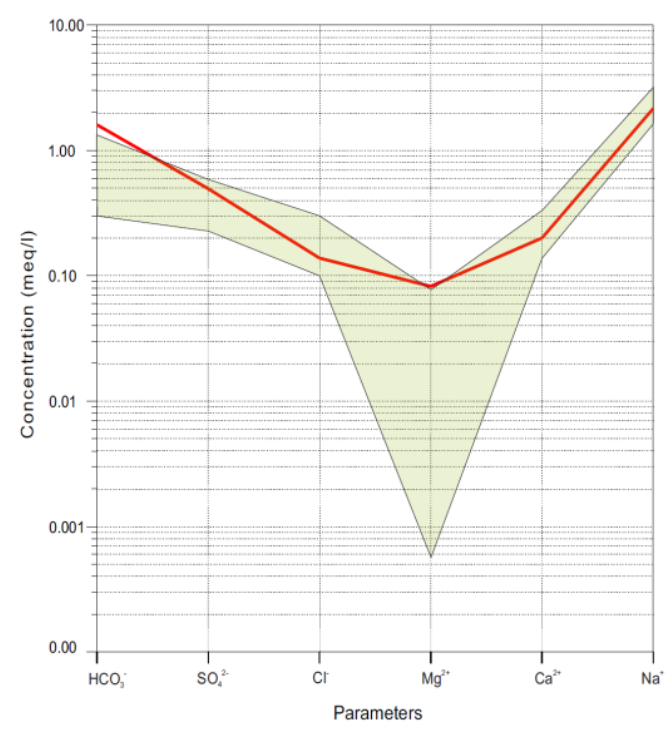

Figure 4. The proportion of major ions in the chemical composition of waters from the LZT-1 borehole as compared to the composition of waters from spa intakes plotted on the Schoeller diagram (based on [79] updated).

When comparing the proportions of particular ions, one can observe little difference between the chemical type of the waters captured by the deep LZT-1 borehole and that of waters extracted in the resort. The major-cation concentrations fall within their variation range in the spa waters. When it comes to anions, a slightly higher proportion of bicarbonate is noticeable. The geothermal waters compositions are plotted in Figure 5. 


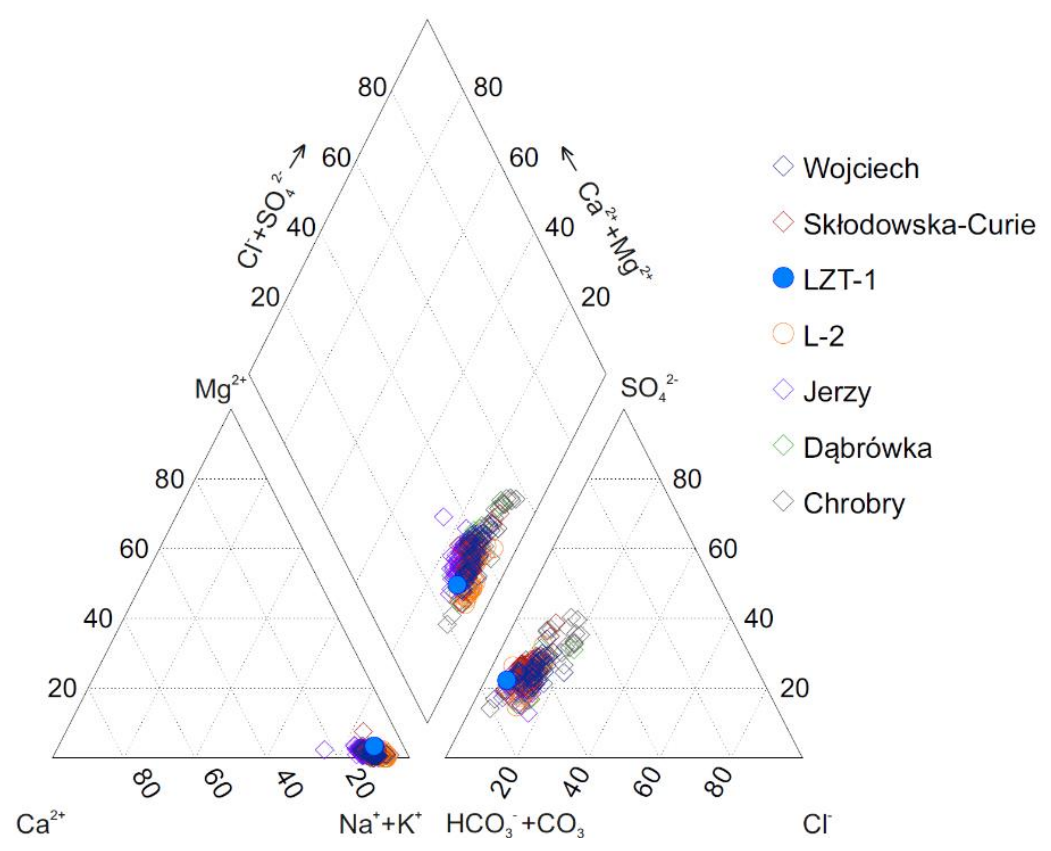

Figure 5. Chemical composition of the Lądek-Zdrój thermal waters on a Piper diagram (based on [79] updated).

This water type suggests that dissolution of silicate might be the source of $\mathrm{Na}^{2+}$. The silicate and carbonate rocks dissolution might be responsible for bicarbonates concentration.

\subsection{Estimation of Reservoir Temperature}

Using several chemical geothermometers (quartz, chalcedony, $\mathrm{Mg}$-Li) and isotope equilibriums of oxygen in the $\mathrm{SO}_{4}-\mathrm{H}_{2} \mathrm{O}$ system, Porowski [48] estimated a probable water temperature range for all Ladek-Zdrój intakes as c. $30^{\circ} \mathrm{C}-\mathrm{c} .91^{\circ} \mathrm{C}$. The studied waters contained $\mathrm{H}_{2} \mathrm{~S}$ originating from bacterial reduction processes, so the use of an oxygen geothermometer in a $\mathrm{SO}_{4}-\mathrm{H}_{2} \mathrm{O}$ system might produce unreliable results. Keeping this in mind, Porowski and Dowgiałło [49] corrected the temperatures of Ladek waters to the range from c. $48^{\circ} \mathrm{C}$ to c. $57^{\circ} \mathrm{C}$.

The temperatures of waters from the discussed borehole LZT- 1 obtained with the use of chalcedony and quartz geothermometers did not differ significantly from the values determined by Porowski and Dowgiałło [49] for medicinal waters. Major discrepancies, of the order of $7-45.5^{\circ} \mathrm{C}$, were observed with geothermometers based on ionic ratios of sodium, potassium, and calcium (Table 4). The magnesium correction for the Na-K-Ca chemical geothermometer [80] was taken into account when estimating the temperature in LZT-1. This very likely affected the difference in these temperatures. In fact the value obtained with the Na-K-Ca geothermometer was higher than the temperature given by Porowski and Dowgiałło [49]. However, Dowgiałło [81] estimated a similar value for the Wojciech spring $\left(98^{\circ} \mathrm{C}\right)$ and an even higher one for the L-2 intake $\left(111^{\circ} \mathrm{C}\right)$.

The results obtained by using a quartz geothermometer, allowing for the results of Arnórsson's research [19], should be approached with some reserve. As the authors report, in the case of waters containing silica in amounts below $50 \mathrm{ppm}$ (in LZT-1 it is $35.7 \mathrm{mg} / \mathrm{L}$ $\mathrm{SiO}_{2}$ ), the temperature estimated with this thermometer did not exceed $100{ }^{\circ} \mathrm{C}$. This was due to the solubility of quartz $(48 \mathrm{ppm})$ at a temperature of about $100{ }^{\circ} \mathrm{C}$. The research by Reed and Spycher [82] suggests that the results from the Na-K geothermometer should also be considered with caution (c. $97^{\circ} \mathrm{C}$-Table 4$)$. The authors claim that the value obtained in conditions of simultaneous equilibria of sodium and potassium aluminosilicates (e.g., albite-microcline) could be regarded as reliable. 
Table 4. Estimated deposit temperature of water $\left({ }^{\circ} \mathrm{C}\right)$ from LZT-1 intake against deposit temperatures of waters from the Lądek-Zdrój intakes (min.-max. temperature ranges are given for springs).

\begin{tabular}{cccccc}
\hline & $\mathbf{Q}\left({ }^{\circ} \mathbf{C}\right)$ & $\mathbf{C h}_{\mathbf{1}}\left({ }^{\circ} \mathbf{C}\right)$ & $\mathbf{C h}_{\mathbf{2}}\left({ }^{\circ} \mathbf{C}\right)$ & Na-K $\left({ }^{\circ} \mathbf{C}\right)$ & Na-K-Ca $\left({ }^{\circ} \mathbf{C}\right)$ \\
\hline \multicolumn{5}{c}{ (Porowski and Dowgiałło, [49]) } \\
\hline springs & $79.6-86.1$ & $48.3-55.1$ & $51.0-57.4$ & $68.4-89.5$ & $29.6-51.3$ \\
L-2 & 78.9 & 47.5 & 50.3 & 76.8 & 36.7 \\
\hline \multicolumn{5}{c}{ current research } \\
\hline LZT-1 & 86.7 & 55.8 & 58.1 & 97.2 & $96.8 *$ \\
\hline * allowing for a $\Delta \mathrm{T}_{\mathrm{Mg}}$ correction $[80]$.
\end{tabular}

Arnórsson et al. [10] argue that temperatures estimated with the Na-K geothermometer reflect the temperatures of deep aquifer systems, whose equilibria slowly evolve, while waters flow towards the surface. Thus, it could be assumed that the temperature of water in the LZT-1 borehole reached at the deposit depth was about $97^{\circ} \mathrm{C}$. On the other hand, the slightly lower $\left(86.7^{\circ} \mathrm{C}\right)$ temperatures estimated with the quartz geothermometer might be evidence of a lack of equilibrium between the water-rock system within the deposit and minerals containing sodium and potassium ions [47]. It was not out of the question then that the concentration of silica was buffered by precipitation of quartz [82].

The Na-K-Ca thermometer proposed by Fournier and Truesdell [17] estimated the deposit temperature to be about $97^{\circ} \mathrm{C}$. It gives more reliable results in comparison to $\mathrm{Na}-\mathrm{K}$ geothermometer for low-temperature geothermal waters $[17,22,78]$. Furthermore, it does not give misleading results for cold- and low-temperature, non-equilibrated systems [20]. However, Zang [83] argued that cationic geothermometers cannot be used to obtain temperature for immature or partially equilibrated waters. In this case, the quartz geothermometer gives a better estimation. As can be seen, the geothermometry reliability for temperature estimation of low-enthalpy systems is controversial.

It should be noted that geothermometers do not estimate maximum reservoir temperature. At best, they give information on the geothermal system temperature at which the chemical equilibrium was attained [20].

\subsection{Variation in the Physicochemical Parameters of Ladek Waters in Longstanding Operation Conditions}

The medicinal thermal waters of Lądek-Zdrój, formed mainly within Gierałtów gneisses, are part of a deep groundwater circulation system. The extracted waters are characterized by a low TDS content, in the range of $160-230 \mathrm{mg} / \mathrm{L}$, and a $\mathrm{pH}$ range of 8-9.9. The highest mean value of the TDS content was characteristic of waters from borehole L-2, followed by waters from springs Chrobry, Wojciech, Skłodowska-Curie, Dabrówka, and Jerzy (Table 5 and Figure 6). These are $\mathrm{Na}-\mathrm{HCO}_{3}-\left(\mathrm{SO}_{4}\right)$ type waters. Owing to increased fluoride $\left(\mathrm{F}^{-}\right)$ion, hydrogen sulfide $\left(\mathrm{H}_{2} \mathrm{~S}\right)$ and radon $\left({ }^{222} \mathrm{Rn}\right)$ activity concentrations, as well as increased temperatures (Table 5), they are classified as fluoride, sulfide, and radon thermal waters.

They are also characterized by very similar relative proportions of major ions in their chemical compositions (Table 5), with a predominance of bicarbonate (15-100\% meq), sulfate (10-36\% meq), and sodium (57-91\% meq) ions. Apart from temperature, their medicinal properties are defined by increased amounts of dissolved gases (radon and hydrogen sulfide), as well as fluoride ions (Table 5).

The periods of reduction in the TDS content in waters observed over several decades generally correspond to the periods of changes in intake exploitation identified by LiberMadziarz [67]. The biggest changes were apparent in 1965, when maintenance/renovation works were conducted on all intakes. The next such period occurred in 1972-1976, when the L-1 and L-2 boreholes were drilled, and hydrodynamic tests were performed on the L-2 intake. The years 1976-1986 could be interpreted as a period of slow stabilization of the conditions of deep-circulation thermal water inflow to the intakes. An incidental drop 
in TDS content apparent in 1978 probably reflects the excessive extraction of plain waters from the L-1 borehole. A renewed decrease in the TDS value in the waters of all intakes in 1987 was probably related to renovation works in Wojciech intake and the formation of new conditions of thermal water inflow. The largest TDS decline observed in the late 1990s was the springs' response to the 1997 flood (Figure 6). A minor variation in 2006 was probably caused by changing the laboratory conducting water analyses (information from the geological staff of the health resort).

Table 5. Minimum and maximum concentrations of major ions and specific components (in years 1965-2016) expressed by a simplified version of Kurlov's formula and the volume of exploitable water resources (based on [65,72,79]).

\section{Intake}

(N)

Chrobry

(54)

Dąbrówka

(54)

Jerzy

Skłodowska-Curie

Wojciech

L-2

(39)

LZT-1

(1)

\section{Kurlov's Formula}

$$
\begin{gathered}
\mathrm{F}^{7-11.5} \mathrm{Rn}^{126-185} \mathrm{H}_{2} \mathrm{~S}^{0.9-3.7} \mathrm{M}^{0.18-0.22} \frac{\mathrm{HCO}_{3}{ }^{21-64} \mathrm{SO}_{4}^{11-28}}{\mathrm{Na}^{87-92}} \mathrm{~T}^{22-27} \\
\mathrm{~F}^{7-11} \mathrm{Rn}^{122-178} \mathrm{H}_{2} \mathrm{~S}^{1-3.7} \mathrm{M}^{0.17-0.22} \frac{\mathrm{HCO}_{3}{ }^{15-50} \mathrm{SO}_{4}^{13-36}}{\mathrm{Na}^{57-99}} \mathrm{~T}^{18-21} \\
\mathrm{~F}^{7-11} \mathrm{Rn}^{1076-1336} \mathrm{H}_{2} \mathrm{~S}^{1-2.5} \mathrm{M}^{0.16-0.21} \frac{\mathrm{HCO}_{3}^{23-53} \mathrm{SO}_{4}^{10-24}}{\mathrm{Na}^{75-90} \mathrm{Ca}^{9-23}} \mathrm{~T}^{27-29} \\
\mathrm{~F}^{7-11} \mathrm{Rn}^{189-474} \mathrm{H}_{2} \mathrm{~S}^{0.2-2.6} \mathrm{M}^{0.17-0.23} \frac{\mathrm{HCO}_{3}{ }^{20-53} \mathrm{SO}_{4}^{15-36}}{\mathrm{Na}^{82-91}} \mathrm{~T}^{22-26} \\
\mathrm{~F}^{7.5-12} \mathrm{Rn}^{170-266} \mathrm{H}_{2} \mathrm{~S}^{0.7-3.9} \mathrm{M}^{0.18-0.23} \frac{\mathrm{HCO}_{3}{ }^{22-50} \mathrm{SO}_{4}^{11-30}}{\mathrm{Na}^{84-91}} \mathrm{~T}^{27.5-30} \\
\mathrm{~F}^{6.8-13} \mathrm{Rn}^{96-181} \mathrm{H}_{2} \mathrm{~S}^{2.6-5.1} \mathrm{M}^{0.2-0.23} \frac{\mathrm{HCO}_{3}{ }^{17-62} \mathrm{SO}_{4}^{12-23}}{\mathrm{Na}^{82-91}} \mathrm{~T}^{41-44.7} \mathrm{Rn}^{94} \mathrm{M}^{0.2} \frac{\mathrm{HCO}_{3}{ }^{57} \mathrm{SO}_{4}^{20}}{\mathrm{Na}^{87} \mathrm{~T}^{37}}
\end{gathered}
$$

anions, cations (\% meq/L); F, H2S (mg/L); Rn (Bq/L); M (g/L); T ( $\left.{ }^{\circ} \mathrm{C}\right) ;{ }^{*}$ —-temperature at the wellhead; $\mathrm{N}$-number of samples.

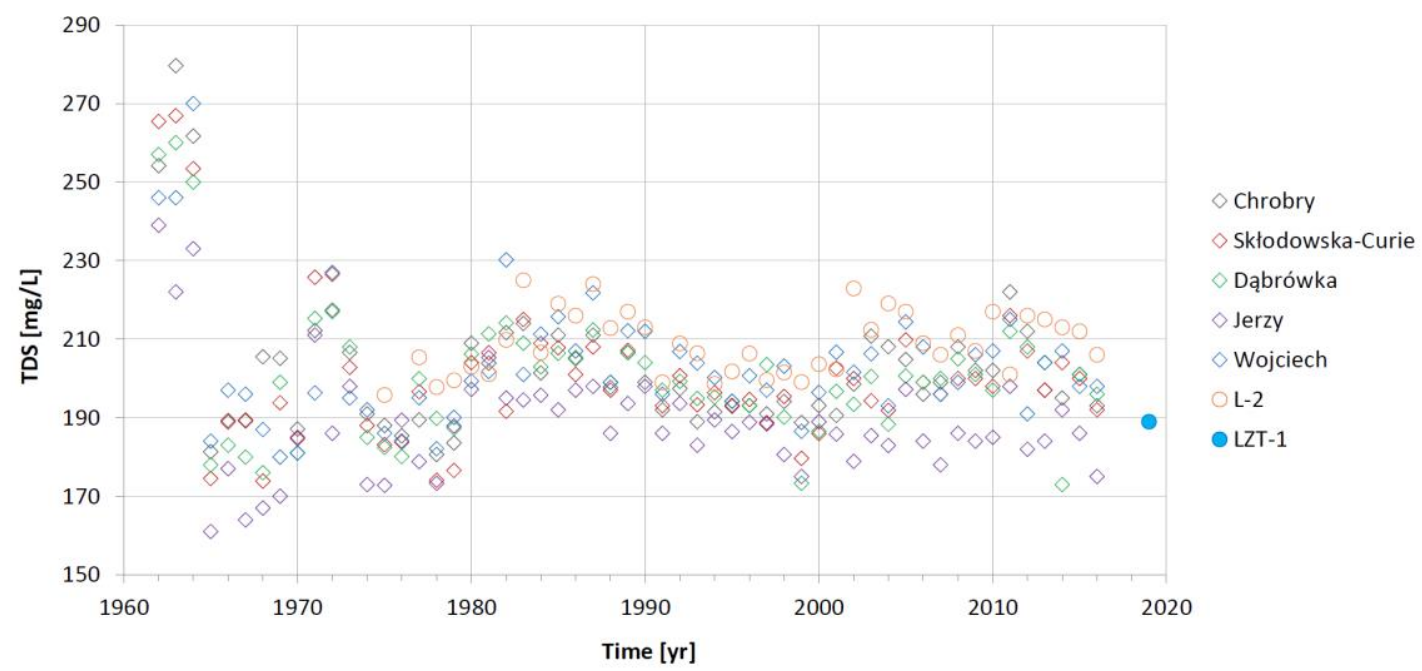

Figure 6. Temporal variation in TDS content in waters from particular intakes (based on [43,44,79] updated); symbols: diamond-spring, and circle-borehole.

The above observations confirmed the hypothesis by Ciężkowski [42] and LiberMadziarz [67] of mutual dynamic interaction between plain water and thermal water deposits and the vulnerability of the whole hydrogeological system of Ladek-Zdrój.

While analyzing the proportions of major ions in all Ladek deposit, one can observe that a rise in calcium ion content comes at the expense of the number of sodium ions with a weak correlation $(\mathrm{R}=-0.44)$. When looking at particular springs, one can observe an inverse relationship between these ions, i.e., an increase in the number of $\mathrm{Ca}^{2+}$ ions within 
particular intakes occurs at an intake-specific rate, but it also co-occurs with a rise in the concentration of sodium ions. The discussed intakes could be ordered according to the $\mathrm{Na}^{+}$content-Jerzy (with the lowest concentration of these ions), Dabrówka, Skłodowska, Wojciech, Chrobry, and L-2 (with waters richest in $\mathrm{Na}^{+}$). These relationships are noted in Figure 7.

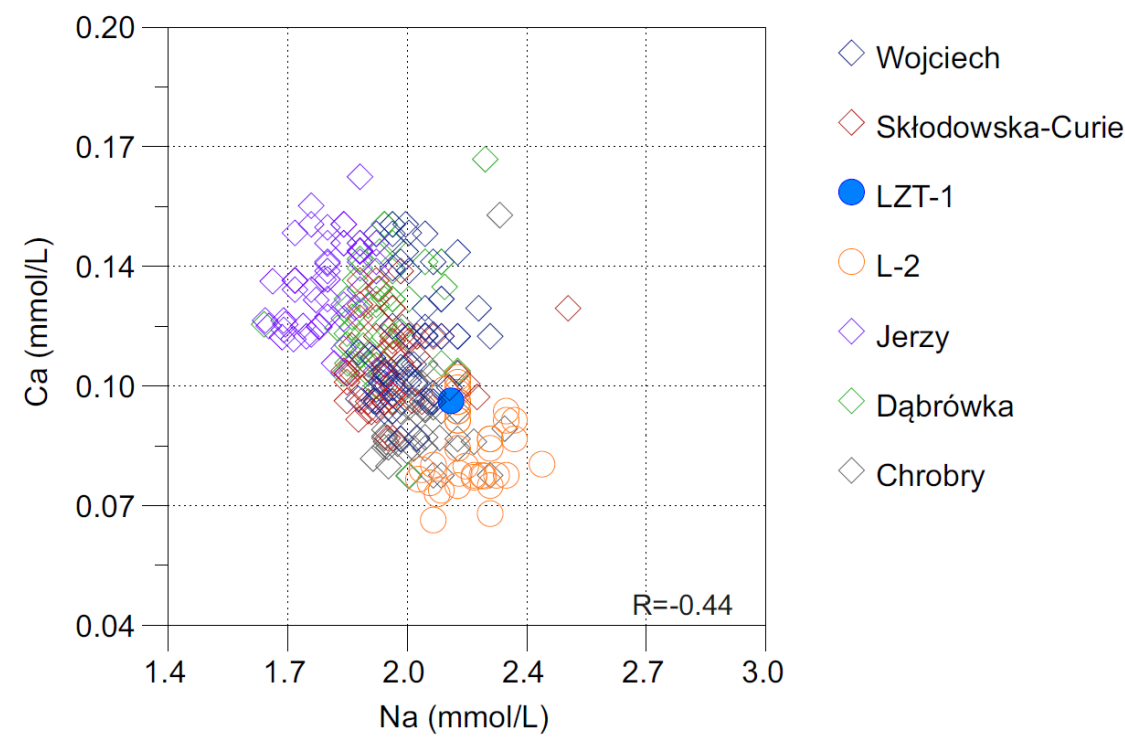

Figure 7. The relationship between the $\mathrm{Na}^{+}$and $\mathrm{Ca}^{2+}$ ion content in waters from particular intakes (based on $[44,84]$ updated).

The gases dissolved in the discussed medicinal waters include increased concentrations of hydrogen sulfide and radon.

The concentrations of $\mathrm{H}_{2} \mathrm{~S}$ dissolved in these waters range from about $0.2 \mathrm{mg} / \mathrm{L}$ (Skłodowska-Curie and Chrobry springs) to a maximum of $5.1 \mathrm{mg} / \mathrm{L}$ (borehole L-2). Waters from Skłodowska-Curie intake sporadically contain slightly higher concentrations of this gas than $1 \mathrm{mg} / \mathrm{L}$. When it comes to Chrobry and Wojciech intakes, the amounts of $\mathrm{H}_{2} \mathrm{~S}$ dissolved in their waters are periodically smaller than the limit value for sulfide waters. Figure 8 shows the concentrations of dissolved $\mathrm{H}_{2} \mathrm{~S}$.

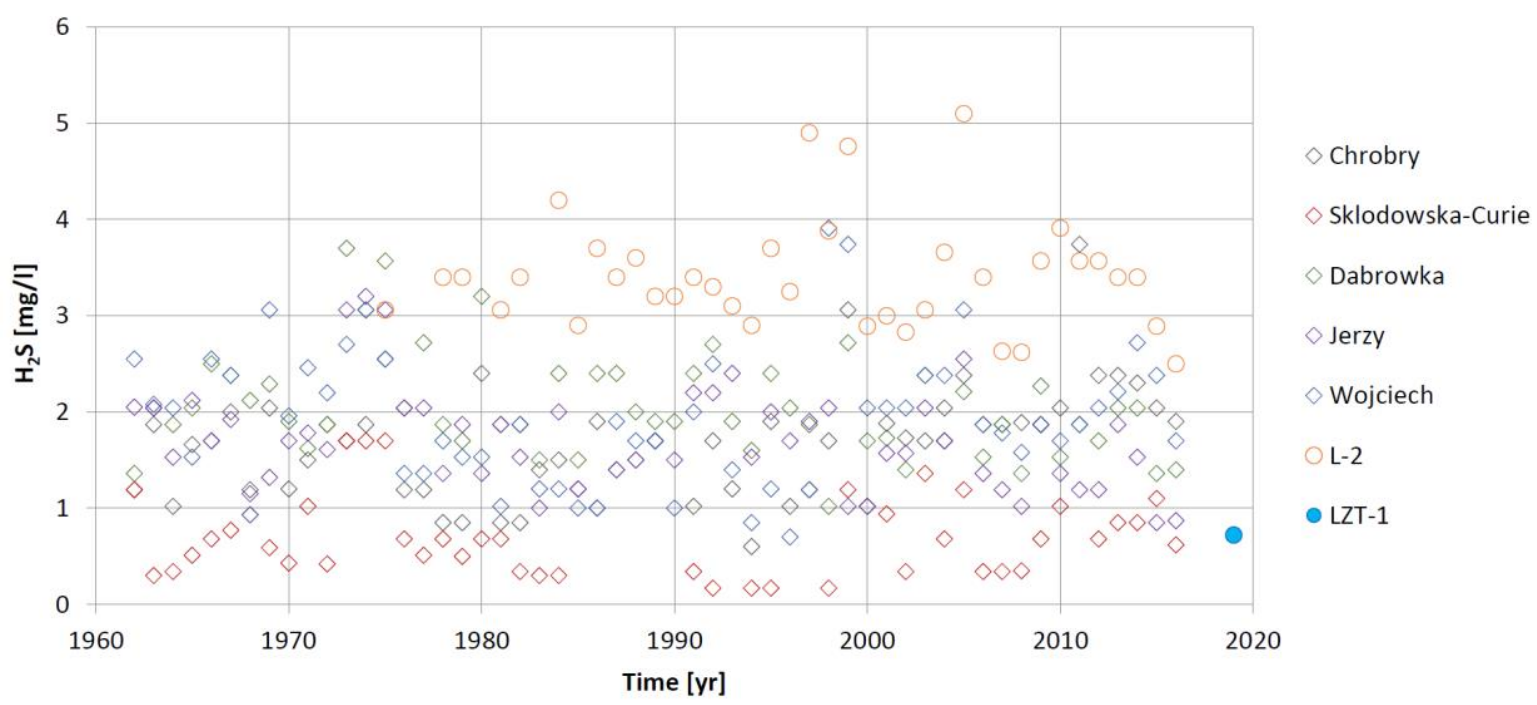

Figure 8. Variation in $\mathrm{H}_{2} \mathrm{~S}$ concentrations dissolved in thermal waters (based on [44] updated). 
The values of local radon background within the Ladek-Śnieżnik metamorphic series range from 0 to the maximum of $92.5 \mathrm{~Bq} / \mathrm{L}(2.5 \mathrm{nCi} / \mathrm{L})$. The radioactivity of Ladek waters results from the presence of dissolved radon $\left({ }^{222} \mathrm{Rn}\right)$. The locations of springs containing water with increased Rn activity concentrations (over $74 \mathrm{~Bq} / \mathrm{L}$ ) correspond to the strike of dislocation zones. The mean ${ }^{222} \mathrm{Rn}$ activity concentrations in spa intakes exceed $100 \mathrm{~Bq} / \mathrm{L}$. In the Jerzy intake, the concentrations of this gas are even higher than $1000 \mathrm{~Bq} / \mathrm{L}$. The amount of radon dissolved in waters decreases with a rise in the depth of the captured water horizon $[5,43,56]$. Waters flowing out of natural springs are characterized by radon activity concentrations of up to c. $1535 \mathrm{~Bq} / \mathrm{L}$, while those extracted from the intakes L-2 and LZT-1 were $181 \mathrm{~Bq} / \mathrm{L}$ and $94 \mathrm{~Bq} / \mathrm{L}$, respectively [56,72].

\subsection{Formation of the Chemical Composition of Waters}

Ciężkowski [63] suggested the main processes shaping the chemistry of Ladek waters were the weathering of feldspar and partial sodium and calcium ion exchange. Numerical modelling results $[51,52]$ are generally consistent with these hypotheses. An analysis of the degree of their saturation with rock-forming minerals demonstrated their slight oversaturation or equilibrium with calcium carbonate, quartz, chalcedony, and fluorite. Waters from deep intakes (L-2, LZT-1) are strongly oversaturated with hydrated magnesium silicates as well as iron oxides and hydroxides, chlorites, zeolites, and muscovite. Plagioclase group minerals, potassium-magnesium micas and amphiboles are dissolved in water. The highest values of the saturation index for all analyzed minerals are characteristic of waters from the LZT-1 borehole. Saturation indices of the studied waters are presented in Figure 9.

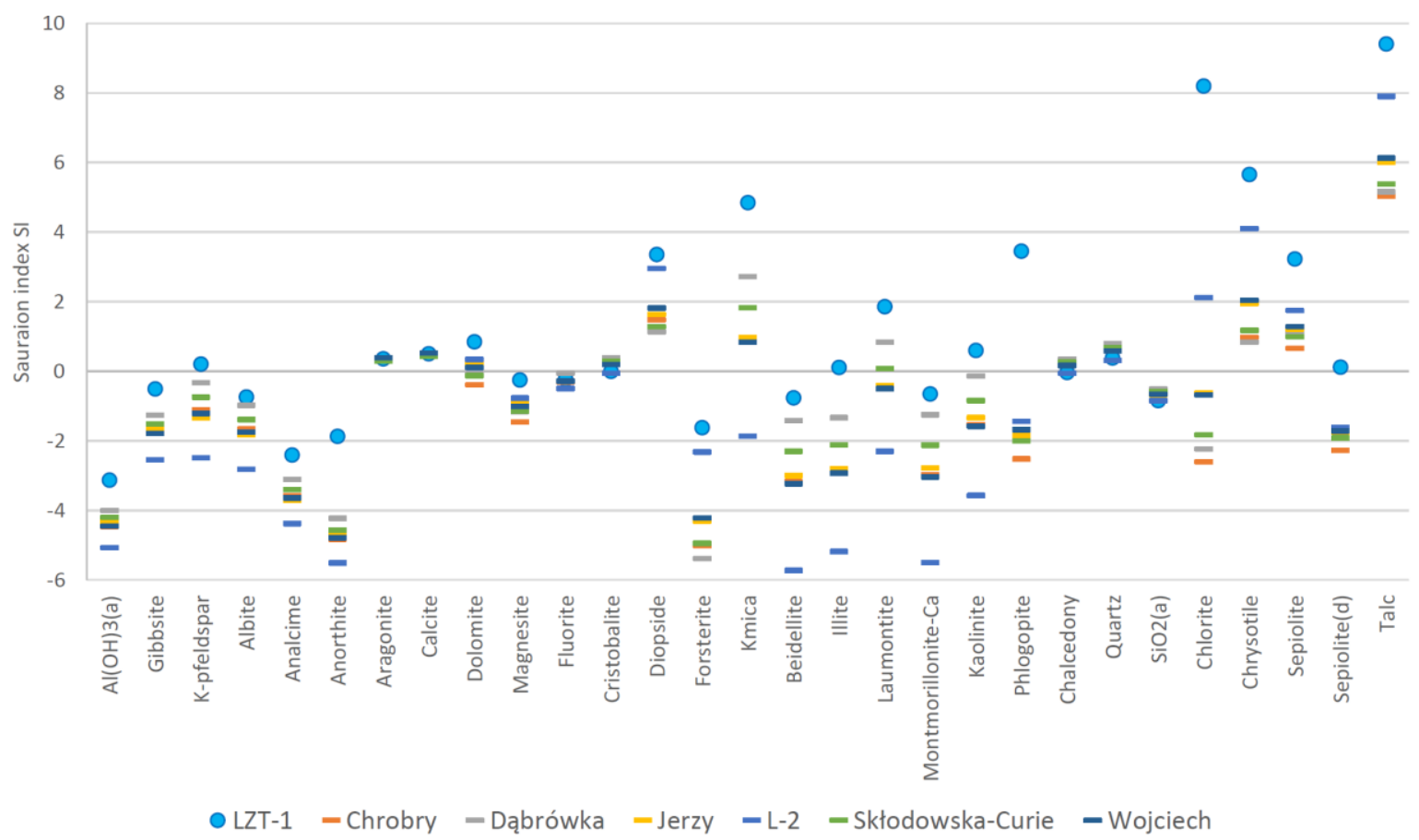

Figure 9. The saturation index (SI) of thermal waters for the selected minerals in the Ladek-Zdrój area (based on [44] updated).

According to Zuber et al. [45] and Ciężkowski et al. [46], recharge areas of the medicinal water deposit in Ladek-Zdrój stretch to the SE of the resort. Given the lithological diversity of rocks in these areas, it can be said that calcium ions present in the studied waters originate from pyroxenes, amphiboles, calcite, and to a lesser extent-calcium plagioclases and fluorite. The presence of sodium and potassium ions should be associated with large proportions of sodium plagioclases (albite, oligoclase andesine), and microcline and orthoclase in the mineral composition of the rock medium $[85,86]$. Mutual ratios 
between the concentrations of $\mathrm{Na}^{+}$ions and silica suggest that water enrichment with these component is the result of the weathering of the above aluminosilicates. Oversaturation of waters with magnesium silicates is, in all likelihood, the result of the weathering of the abovementioned pyroxenes, amphiboles, and magnesium micas.

When it comes to fluoride ions, their key source in groundwaters could be fluorite $\left(\mathrm{CaF}_{2}\right)$, fluorapatite $\left(\mathrm{Ca}_{5}(\mathrm{Cl}, \mathrm{F}, \mathrm{OH})\left(\mathrm{PO}_{4}\right)\right)$, and cryolite $\left(\mathrm{Na}_{3} \mathrm{AlF}_{6}\right)$. Other potentially fluorinebearing minerals could be amphiboles (hornblende, tremolite), micas (biotite, phlogopite, muscovite), tourmalines, topaz, as it is in the structures of these minerals where mutual replacement of the $\mathrm{OH}^{-}$group and the $\mathrm{F}^{-}$ion can take place [87].

The waters from the Ladek deposit are characterized by the $\mathrm{F}^{-}$ion content between c. $7 \mathrm{mg} / \mathrm{L}$ and the maximum of $13 \mathrm{mg} / \mathrm{L}$. The concentrations of this component increase with intake depth, and the hydrochemical background of fluorine in shallow fissure waters and springs flowing out of the southern slopes of Śnieżnik do not exceed $0.5 \mathrm{mg} / \mathrm{L}$ [43].

Figure 10 shows the correlation $(\mathrm{R}=0.54)$ between the concentrations of $\mathrm{F}^{-}$and $\mathrm{Na}^{+}$ ions and it points to silicates or aluminosilicates as the source of fluorine in the studied waters. These are probably micas (biotite, muscovite, and lepidolite), hornblende, and secondarily apatite-minerals building mica and amphibolite schists, as well as amphibolites [88].

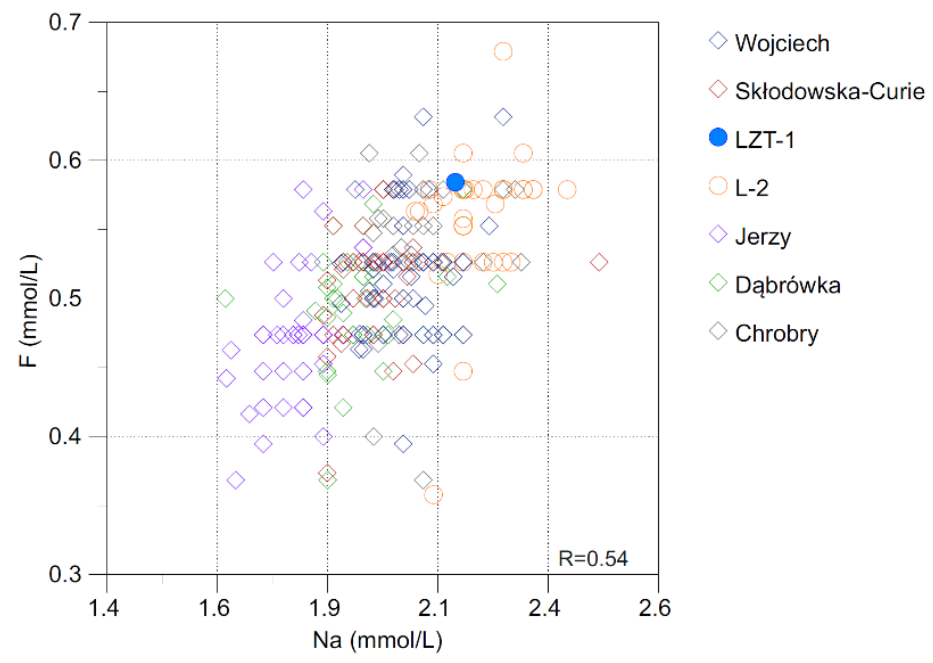

Figure 10. Variation in the F- ion concentration depending on the Na+ ion content (based on [79] updated).

A weaker correlation $(\mathrm{R}=-0.35)$ between the proportions of $\mathrm{F}^{-}$and $\mathrm{Ca}^{2+}$ ions suggests fluorite as their possible supplementary source in the waters of particular intakes (Figure 11). The dissolution rate of this mineral depends on the concentration of $\mathrm{Ca}^{2+}$ ions. A rise in this value might cause precipitation of secondary calcite. Moreover, by supplying water with major cations $\left(\mathrm{Na}^{+}, \mathrm{K}^{+}, \mathrm{Ca}^{2+}, \mathrm{Mg}^{2+}\right)$ and bicarbonate ions, dissolving silicates and aluminosilicates enable precipitation of secondary calcite, which in turn leads to increased fluorite dissolution [89]. This process seems plausible, as secondary forms of calcium carbonate were observed in borehole cores [63,72] and rock samples [86] Additional calcium ions could be supplied by dissolved hornblende, apatite, and plagioclases. 


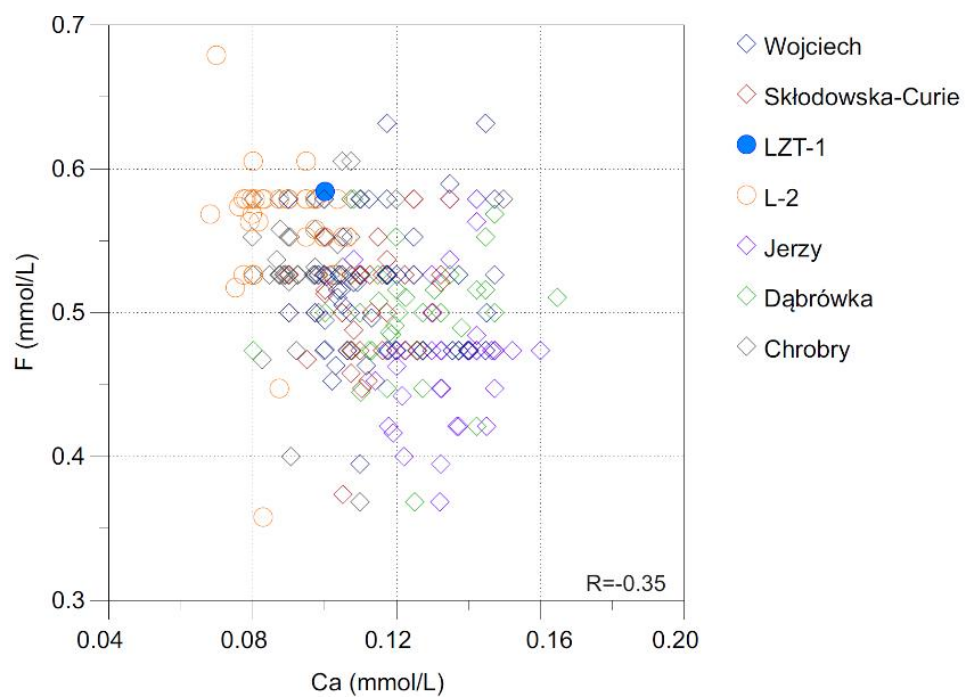

Figure 11. Correlation between the $\mathrm{F}^{-}$and $\mathrm{Ca}^{2+}$ ion content (based on [79] updated).

Gierwielaniec [36], and Gierwielaniec and Szarszewska [90] suggested the origin of fluoride ions in the weathering of fluorite occurring south of Ladek-Zdrój, in the area of the Kletno overthrust. Owing to the insignificant apatite occurrence within the gneiss series, the origin of these ions as a result of the weathering of this mineral seemed less plausible. Increased concentrations of fluorides in the studied waters were evidence of their fast outflow from the deposit and the lack of or insignificant mixing with plain waters from the shallow circulation system [2].

While analyzing variation in sodium and fluoride ion concentrations, Zuber et al. [45] proposed that the mixing of waters from the Ladek deposit with cooler waters with lower TDS content did not exceed $20-25 \%$.

As already mentioned, the waters in the studied deposit were characterized by low TDS content and alkaline $\mathrm{pH}$. The amount of $\mathrm{CO}_{2}$ dissolved in them was so low that the weak carbonic acid formed as a result of the dissolution of this gas did not significantly lower the $\mathrm{pH}$ of these waters. The high alkalinity of these waters and their increased temperature, even with low concentrations of $\mathrm{Ca}^{2+}$ and $\mathrm{Mg}^{2+}$, results in precipitation of secondary minerals. The former of the two ions is bound in calcite, montmorillonite, and zeolites. Magnesium ions are bound in talc and chlorites, $\mathrm{Na}^{+}$in albite, and $\mathrm{K}^{+}$in kaolinite, illite, muscovite, and phlogopite. Iron released from dissolution of pyrite and biotite is bound in hydroxides. In the described $\mathrm{pH}$ and water temperature conditions, the hydrolysis reaction constants are low $[14,15]$, so the components quickly reach the solution precipitate in the form of secondary minerals, despite their low concentrations. This leads to equilibration of the components that get to the solution, as a result of the reaction of waters with the rock medium and the precipitated minerals. The result is a low TDS content in these waters.

In fissured zones, the weathering of plagioclases results in the occurrence of their hydrated forms, i.e., zeolites (laumontite, stilbite, and analcime). In areas with thermal water occurrence, laumontite is the most common [91]. Ca-zeolites bind calcium ions present in solutions, causing enrichment of thermal waters with $\mathrm{Na}^{+}$and $\mathrm{F}^{-}$ions. The described processes are demonstrated, for example, by the weathering reaction of albite in the presence of fluorite:

$$
2 \mathrm{NaAlSi}_{3} \mathrm{O}_{8}+\mathrm{CaF}_{2}+4 \mathrm{H}_{2} \mathrm{O}=\mathrm{Ca}\left(\mathrm{Al}_{2} \mathrm{Si}_{4} \mathrm{O}_{12}\right) \cdot 4 \mathrm{H}_{2} \mathrm{O}+2 \mathrm{SiO}_{2}+2 \mathrm{Na}^{+}+2 \mathrm{~F}^{-}
$$

However, at a temperature of $45^{\circ} \mathrm{C}$ and with the participation of secondary calcite and pyrite, another calcium zeolite-stilbite could be formed [16]: 
In Śnieżnik gneisses, where pyrite occurs in the form of mineralization and albite is much more abundant, the above reaction occurs until all pyrite is altered [16].

\section{Summary and Conclusions}

The main goals of these studies were to obtain information about the geothermal fluids chemistry and reservoir temperature. The drilling of the LZT-1 borehole enabled establishing the occurrence at depths of $2-2.5 \mathrm{~km}$ of geothermal waters, with a TDS content of about $190 \mathrm{mg} / \mathrm{L}$, which do not differ from the TDS of spa intakes. The $\mathrm{Na}-\mathrm{HCO}_{3}-\left(\mathrm{SO}_{4}\right)$, $\mathrm{F}, \mathrm{H}_{2} \mathrm{~S}, \mathrm{Rn}$ chemical composition is similar to that of waters captured in springs and in the L-2 borehole.

At the outflow from the LZT- 1 borehole, the temperature of water, discharged at the rate of $10 \mathrm{~m}^{3} / \mathrm{h}$, reaches $37.4{ }^{\circ} \mathrm{C}$, and at the bottom of the heated borehole, it is $58.9^{\circ} \mathrm{C}$. Results of the first part of the hydrodynamic test show the hydraulic connection between LZT-1 and L-2 wells. The exploitable reserves or the LZT-1 are not established.

The source of calcium ions in the studied waters are pyroxenes, amphiboles, calcite, calcium plagioclases, and fluorite. In the case of sodium and potassium ions, they originate from sodium plagioclases, microcline, and orthoclase.

Based on an analysis of the physicochemical properties of waters from the LZT-1 borehole, the reservoir temperature was estimated by using chemical geothermometers. The probable temperature reached by waters from the LZT- 1 borehole in the reservoir falls within the range of about $87^{\circ} \mathrm{C}$ to $\mathrm{c} .97^{\circ} \mathrm{C}$. The most likely results obtained with the use of chemical geothermometers are those for waters in the state of thermodynamic equilibrium with a rock medium. The Ladek waters are characterized by undersaturation in relation to almost all rock-forming minerals of the rock medium, through which these waters flow. Hence, one should be cautious while drawing conclusions from research using geothermometers for waters exhibiting even partial equilibrium [51,92].

It is very difficult today to discuss the implication of the results with respect to geothermal energy because of the lack of a detailed hydrogeological test. During the first part of measurements, the negative influence on the pressure at the L-2 wellhead was observed. It was planned currently to carry out these tests as a second part of the reservoir exploration. The program of hydrodynamic tests was drawn up for LZT- 1 and springs and L-2 borehole. Results of the long-term tests can characterise the hydraulic system. The main assumption was to use the geothermal energy from this reservoir for space heating. Furthermore, the unusual combination of sodium bicarbonates and fluoride, hydrogen sulfide, radon, and temperature, suggest that the water can be utilized in balneotherapy. Low-enthalpy water might be used for the heating of greenhouses, swimming pools, and providing hot water for domestic use. The decision about the method of utilization will be made after all planned works.

Author Contributions: The authors contributed in the following categories: conceptualization, W.C. and B.K.; methodology, B.K. and W.C.; software, B.K.; formal analysis, B.K. and W.C.; investigation, B.K., W.C. and M.R.; resources, B.K., W.C., M.W. and M.R.; data curation, B.K. and W.C.; writingoriginal draft preparation, B.K.; writing—review \& editing, B.K., W.C., M.W. and M.R.; visualization, B.K. All authors have read and agreed to the published version of the manuscript.

Funding: The APC was funded by the Department of Mining, Faculty of Geoengineering, Mining and Geology of Wrocław University of Science and Technology.

Institutional Review Board Statement: Not applicable.

Informed Consent Statement: Not applicable.

Data Availability Statement: Data available on request due to restrictions.

Acknowledgments: The authors thank the mayor of Ladek-Zdrój and the Board of Directors of the Ladek-Długopole Health Resort for providing access to materials and enabling the research. The authors also thank the Department of Mining of Wrocław University of Science and Technology for support during the preparation and publication of this paper. 
Conflicts of Interest: The authors declare no conflict of interest.

\section{References}

1. Franko, O.; Kolářová, M.; Mateovič, L. Catalogue of Documental Points to the Map of Mineral Waters in Czechoslovakia, 1:500,000, 1st ed.; Dionýz Štúr Institute of Geology—Central Institute of Geology: Praha, Czech Republic, 1985.

2. Janoška, M. Minerální prameny v Čechách, na Moravě a ve Slezsku, 1st ed.; Academia: Praha, Czech Republic, $2011 ;$ p. 495.

3. Franko, O.; Kolářová, M. Explanations to the Map of Mineral Waters in Czechoslovakia, 1:500,000, 1st ed.; Dionýz Štúr Institute of Geology-Central Institute of Geology: Bratislava, Praha, 1985.

4. Dowgiałło, J. Wody termalne Sudetów. Acta Geol. Pol. 1976, 26, 617-643.

5. Ciężkowski, W. Studium Hydrogeochemii wód Leczniczych Sudetów Polskich; Pr. Nauk. Instyt. Geotech. PWr.; Wydawnictwo Politechniki Wroclawskiej: Warszawa, Poland, 1990; pp. 1-130.

6. Albu, M.; Banks, D.; Nash, H. Hydrogeochemistry and origin of mineral waters. In Mineral and Thermal Groundwater Resources, 1st ed.; Albu, M., Banks, D., Nash, H., Eds.; Chapman \& Hall: London, UK, 1997; pp. 48-100.

7. Papič, P. Mineral and Thermal Waters of Southeastern Europe, 1st ed.; Springer: Basel, Switzerland, $2016 ;$ p. 171.

8. Balderer, W.; Porowski, A.; LaMoreaux, J.W. Thermal and Mineral Waters. Origin, Properties and Applications, 1st ed.; Springer: Basel, Switzerland, 2014; p. 135.

9. Bundschuh, J.; Tomaszewska, B. Geothermal Water Management, 1st ed.; CRC Press Taylor \& Francis Group: London, UK, 2018; p. 462.

10. Arnórsson, S.; Gunnlaugsson, E.; Svavarsson, H. The chemistry of geothermal waters in Iceland. III. Chemical geothermometry in geothermal investigations. Geochim. Cosmochim. Acta 1983, 47, 547-566. [CrossRef]

11. Fournier, R. Application of water geochemistry to geothermal exploration and reservoir engineering. In Geothermal Systems: Principles and Case Histories, 1st ed.; Rybach, L., Muffler, L.P., Eds.; John Willey \& Sons Ltd.: Chichester, UK, 1981 ; pp. $109-143$.

12. Pačes, T. Chemical characteristics and equilibration in natural water-felsic rock-CO $\mathrm{CO}_{2}$ system. Geochim. Cosmochim. Acta 1972, 36, 217-240. [CrossRef]

13. Stober, I.; Bucher, K. 2005, The upper continental crust, an aquifer and its fluid: Hydraulic and chemical data from $4 \mathrm{~km}$ depth in fractured crystalline basement rocks at the KTB test site. Geofluids 2005, 5, 8-19.

14. Shvartsev, S.L.; Zamana, L.V.; Plyusnin, A.M.; Tokarenko, O.G. Equilibrium of nitrogen-rich spring waters of the Baikal Rift Zone with host rock minerals as a basis for determining mechanisms of their formation. Geochem. Inter. 2015, 53, 720-733. [CrossRef]

15. Shvartsev, S.L.; Sun, Z.; Borzenko, B.; Gao, B.; Tokarenko, O.G.; Zippa, E.V. Geochemistry of the thermal waters in Jiangxi Province. Chin. Appl. Geochem. 2018, 96, 113-130. [CrossRef]

16. Bucher, K.; Stober, I. Fluids in the upper continental crust. Geofluids 2010, 10, 241-253.

17. Fournier, R.O.; Truesdell, A.H. An empirical Na-K-Ca geothermometer for natural waters. Geochim. Cosmochim. Acta 1973, 37, 1255-1275.

18. Fournier, R.O. Chemical geothermometers and mixing models for geothermal systems. Geothermics 1977, 5, 41-50. [CrossRef]

19. Arnórsson, S. Chemical equilibria in Icelandic geothermal systems-implication for chemical geothermometry investigations. Geothermics 1983, 12, 119-128. [CrossRef]

20. Arnórsson, S. The quartz- and Na/K geothermometers. II Results and application for monitoring studies. In Proceedings of the World Geothermal Congress, Tohoku, Japan, 28 May-10 June 2000.

21. Giggenbach, W.F. Geothermal solute equilibria. Derivation of Na-K-Mg-Ca geoindycators. Geochim. Cosmochim. Acta 1988, 52, 2749-2765. [CrossRef]

22. Cave, L.; Clarke, S. A Feasibility Study on the Use of Chemical Geothermometers for Tracing Deep Groundwater Flow; Report to the Water Research Commision No. 1331/1/03; Division of Water, Environment and Forestry Technology: Pretoria, South Africa, 2003.

23. Pfeiffer, L.; Wanner, C.; Spycher, N.; Sonnenthal, E.L.; Kennedy, B.M.; Iovenitti, J. Optimized multicomponent vs. classical geothermometry: Insights from modelling studies at the Dixie Valley geothermal area. Geothermics 2014, 51, 154-169. [CrossRef]

24. Pang, Z.H.; Red, M.H. Theoretical chemical thermometry on geothermal waters: Problems and methods. Geochim. Cosmochim. Acta 1998, 62, 1083-1091. [CrossRef]

25. Jetel, J.; Rybařová, L. Minerální vody Východočeského kraje, 1st ed.; Ústřední ústav geologický: Praha, Czech Republic, $1979 ;$ p. 228.

26. Kačura, G. Minerální vody Severočeského Kraje, 1st ed.; Ústřední ústav geologický: Praha, Czech Republic, $1980 ;$ p. 178.

27. Zötl, J.; Goldbrunner, J.E. Die Mineral und Heilwässer Österreichs, 1st ed.; Springer: Wien, Austria, 1993; p. 329.

28. Sonney, R. Groundwater Flow, Heat and Mass Transport in Geothermal Systems of a Central Alpine Massif. The cases of Lavey-les-Bains, Saint-Gervais-les-Bains and Val d'Illiez. Ph.D. Thesis, Université de Neuchâtel, Neuchâtel, Switzerland, 2010. Available online: https:/ / tel.archives-ouvertes.fr/tel-00923368/file/These-Sonney-2010 (accessed on 28 December 2020).

29. Ricour, J.; Pomerol, C.h. Terroirs et Thermalisme en France Les eaux Minérales Françaises, 1st ed.; Éditions du BRGM: Orleans, France, 1992; p. 288.

30. Baskov, E.A.; Surikov, S.N. Gidrotermi Zemli, 1st ed.; Nedra: Leningrad, Russia, 1989; p. 244.

31. Das, P.; Maya, K.; Padmalal, D. Hydrochemistry, geothermometry and origin of the low temperature thermal springs of South Konkan region India. Geothermics 2021, 90. [CrossRef] 
32. Yaguchi, M.; Muramatsu, Y.; Chiba, H.; Okumura, F.; Ohba, T.; Yamamuro, M. Hydrochemistry and isotopic characteristics of non-volcanic hot springs around the Miocene Kofu granitic complex surrounding the Kofu Basin in the South Fossa Magna region, central Honshu. Jpn. Geochem. J. 2000, 48, 345-356. [CrossRef]

33. Dominikiewicz, M. Wody Mineralne Polski, 1st ed.; Państwowy Zakład Wydawnictw Lekarskich: Warszawa, Poland, $1951 ;$ p. 620.

34. Goebel, S. Analizy Chemiczne wód Mineralnych Polski, 1st ed.; Wyd. Geol.: Warszawa, Poland, 1963; p. 590.

35. Jarocka, A. Analizy fizyko-chemiczne wód leczniczych z polskich uzdrowisk wykonane w 1968 r. Ladek. Probl. Uzdr. 1970, 1, 191-201.

36. Gierwielaniec, J. Lacdek-Zdrój i jego wody mineralne. Kwart. Geol. 1968, 12, 680-692.

37. Gierwielaniec, J. Lądek Zdrój i jego wody mineralne w świetle dotychczasowych badań. Pr. Nauk. Inst. Geotech. PWr. 1970, 5, 23-34.

38. Fistek, J. Wody mineralne Ladka Zdroju. In Przewodnik XXX Zjazdu Polskiego Towarzystwa Geologicznego; Polish Geological Society: Duszniki Zdrój, Poland, 1957; pp. 171-172.

39. Fistek, J.; Szarszewska, Z. Nowe ujęcie wody termalnej w Ląku Zdroju. In Przewodnik XLVII Zjazdu Polskiego Towarzystwa Geologicznego; Polish Geological Society: Świdnica, Poland, 1975; pp. 259-262.

40. Ciężkowski, M.; Ciężkowski, W. Źródła Lądka Zdroju—historia i badania. Balneol. Pol. 1983, $27,5-19$.

41. Ciężkowski, W. Hydrochemical types of fissure waters from Lądek Zdroj. In Proceedings of the Conference Hydrogeochemistry of Mineralized Waters, Cieplice Spa, Poland, 31 May-3 June 1978.

42. Ciężkowski, W. Wody termalne Ląka Zdroju. In Proceedings of the II Ogólnopolskie Sympozjum Współczesne Problemy Hydrogeologii Regionalnej, Ląek-Zdrój, Poland, 13-16 October 1982; Wydawnictwo Uniwersytetu Wrocławskiego: Wrocław, Poland, 1983; pp. 30-40.

43. Ciężkowski, W. Hydrogeologia i hydrochemia wód termalnych Lądka-Zdroju. Probl. Uzdr. 1980, 4, 125-193.

44. Kiełczawa, B. Charakterystyka hydrochemiczna wód termalnych Lądka-Zdroju. Tech. Posz. Geol. Geoterm. Zrównoważony Rozwój 2013, 2, 105-116.

45. Zuber, A.; Weise, S.M.; Osenbrück, K.; Grabczak, J.; Ciężkowski, W. Age and recharge area of thermal waters in Lądek Spa (Sudeten, Poland) deduced from environmental isotope and noble gas data. J. Hydrogeol. 1995, 167, 327-349.

46. Ciężkowski, W.; Doktór, S.; Graniczny, M.; Kabat, T.; Kozłowski, J.; Liber, E.; Przylibski, T.; Teisseyre, B.; Wiśniewska, M.; Zuber, A. Próba Określenia Obszarów Zasilania wód Leczniczych Pochodzenia Infiltracyjnego w Polsce na Podstawie Badań Izotopowych; Zał. 20; Złoże wód leczniczych Lądka-Zdroju; Zakład Badawczo-Usługowy: Wrocław, Poland, 1996; Unpublished.

47. Dowgiałło, J.; Hałas, S.; Porowski, A. Isotope temperature indicators of thermal waters in South-Western Poland. In Proceedings of the World Geothermal Congress, Anatalya, Turkey, 24-29 April 2005.

48. Porowski, A. Sens i znaczenie badań geotermometrycznych w poszukiwaniach wód termalnych o niskiej entalpii. Tech. Posz. Geol. Geoterm. Zrównoważony Rozwój 2007, 46, 69-77.

49. Porowski, A.; Dowgiałło, J. Application of selected geothermometers to exploration of low-enthalpy thermal water: The Sudetic Geothermal Region in Poland. Environ. Geol. 2009, 58, 1629-1638. [CrossRef]

50. Leśniak, P. Some ionic equlibria of Sudetic thermal waters. In Proceedings of the Conference Hydrogeochemistry of mineralized waters, Cieplice Spa, Poland, 1-3 October 1978; pp. 389-394.

51. Leśniak, P.; Nowak, D. Water-rock interaction in some mineral waters in the Sudetes, Poland: Implications for chemical geothermometry. Ann. Soc. Geol. Pol. 1993, 63, 101-118.

52. Dobrzyński, D.; Leśniak, P. Two contrasting geothermal systems-towards the identification of geochemical reaction pattern and groundwater temperature, the Sudetes, Poland. In Proceedings of the Extendend abstracts of 38th IAH Congress, Kraków, Poland, 12-17 September 2010.

53. Ciężkowski, W.; Solecki, A.; Śliwiński, W. Results of the long term monitoring of radon content in mineral springs of the Spa of Lądek Zdrój, southwestern Poland. In Gas Geochemistry; Dubois, C., Ed.; University of Franche-Comté: Besançon, France, 1995; pp. 81-89.

54. Przylibski, T.A.; Żebrowski, A. Origin of radon in medicinal waters of Lądek Zdrój (Sudety Mountains, SW Poland). J. Environ. Radioact. 1999, 46, 121-129.

55. Przylibski, T.A. ${ }^{222} \mathrm{Rn}$ concentration changes in medicinal groundwaters of Ladek Zdrój (Sudety Mountains, SW Poland). J. Env. Radioac. 2000, 48, 327-347. [CrossRef]

56. Przylibski, T.A. Radon. Składnik Swoisty wód Leczniczych Sudetów, 1st ed.; Oficyna Wydawnicza Politechniki Wrocławskiej: Wrocław, Poland, 2005; p. 329.

57. Żelaźniewicz, A. Dzieje Ziemi. Przeszłość geologiczna. In Przyroda Dolnego Ślaska, 1st ed.; Fabiszewski, J., Ed.; PAN Oddział we Wrocławiu: Wrocław-Warszawa, Poland, 2005; pp. 61-134.

58. Gierwielaniec, J. Z geologii Lądka-Zdroju. Pr. Nauk. Inst. Geotech. PWr. 1970, 5, 1-43.

59. Don, J. Góry Złote i Krowiarki jako elementy składowe metamorfiku Śnieżnika. Geol. Sudet. 1964, 1, 117.

60. Birkenmajer, K.; Pecskay, Z.; Grabowski, J.; Lorenc, M.W.; Zagożdżon, P.P. Radiometric dating of the Tertiary volcanics in Lower Silesia, Poland. II. K-Ar dating and paleomagnetic data from Neogene basanites near Lądek-Zdrój, Sudetes Mts. Ann. Soc. Geol. Polon. 2002, 72, 119-129.

61. Jastrzębski, M. The tectonometamorphic evolution of the marbles in the Ladek-Śnieżnik metamorphic unit, West Sudetes. Geol. Sudet. 2005, 37, 1-26. 
62. Fistek, J.; Iwanowski, S.; Iciek, A.; Jagodziński, A. Metody badawcze w poszukiwaniu i rozpoznaniu złóż wód termalnych w sudeckim regionie geotermalnym. Biul. Inform. Geofizyka 1975, 1, 5-30.

63. Ciężkowski, W. Hydrogeologia i Hydrochemia wód Termalnych Lądka Zdroju. Ph.D. Thesis, Wrocław University of Science and Technology, Wrocław, Poland, 1978.

64. Staśko, S.; Tarka, R. Zasilanie i drenaż wód podziemnych w obszarach górskich na podstawie badań w Masywie Śnieżnika. Acta Univ. Wratisl. 2002, 2528, 63.

65. Ciężkowski, W.; Liber-Makowska, E.; Ciekot, B.; Ogórek, A. Charakterystyka warunków występowania i eksploatacji wód termalnych Lądka-Zdroju. Tech. Posz. Geol. Geoterm. Zrównoważony Rozwój 2011, 50, 61-69.

66. Liber-Makowska, E. Dynamiczne oddziaływanie pomiędzy ujęciami wód termalnych Lądka-Zdroju. Tech. Posz. Geol. Geoterm. Zrównoważony Rozwój 2011, 1, 71-80.

67. Liber-Madziarz, E. Charakterystyka wydajności ujęć wód termalnych Lądka Zdroju. In Proceedings of the VIII Ogólnopolskie Sympozjum Hydrogeologiczne, Współczesne Problemy Hydrogeologii, Kiekrz/Poznań, Poland, 4-6 September 1997; Wyd. WIND: Poznań, Poland, 1997; pp. 357-360.

68. Liber, E. Zmienność Wydajności ujęć wód Leczniczych Eksploatowanych Samoczynnie ze Złóż Sudeckich. Ph.D. Thesis, Wrocław University of Science and Technology, Wrocław, Poland, 2001.

69. Liber, E. Charakterystyka opróżniania zbiornika wód szczelinowych głębokiego krążenia na przykładzie złoża wód termalnych Lądka-Zdroju. Biul. PIG 2009, 436, 317-322.

70. Květ, R.; Kačura, G. Minerální vody Severomoravského kraje, 1st ed.; Ústřední Ústav Geologický: Praha, Czech Republic, 1978; p. 173.

71. Sajner, J.; Křížek, V. Lázně Velké Losiny, Dějiny, Přitomnost, Přírodní Zdroje, 1st ed.; Avicenum: Praha, Czech Republic, 1973.

72. Rasała, M.; Ciężkowski, W.; Wąsik, M.; Kiełczawa, B. Dokumentacja geologiczna z wykonania prac geologicznych niekończących się udokumentowaniem zasobów złoża kopaliny w związku z wykonaniem otworu poszukiwawczego za wodami termalnymi LZT-1 w Lądku-Zdroju. Unpublished.

73. Macioszczyk, A. Metody przedstawiania składu chemicznego wód podziemnych. In Hydrogeochemia, 1st ed.; Macioszczyk, A., Ed.; Wyd. Geol.: Warszawa, Poland, 1987; pp. 314-359.

74. Dz.U. Poz. 1064: Obwieszczenie Marszałka Sejmu Rzeczpospolitej Polskiej z dnia 26 Marca 2020 r. w Sprawie Ogłoszenia Jednolitego Tekstu Ustawy; Prawo Geologiczne i Górnicze: Warszawa, Poland, 2020.

75. Porowski, A. Mineral and Thermal Waters. In Encyclopedia of Sustainability Science and Technology, 1st ed.; Meyers, R., Ed.; Springer: New York, NY, USA, 2018. [CrossRef]

76. Blasco, M.; Auqué, L.F.; Gimeno, M.J. Application of different geothermometrical techniques to a low enthalpy thermal system. Proc. Earth Planetary Sci. 2017, 17, 65-68. [CrossRef]

77. Fournier, R. Lectures on Geochemical Interpretation of Hydrothermal Waters, UNU-Geothermal Training Programme; Report 10; The United Nations University: Reykjavik, Iceland, 1989; p. 731. Available online: http://orkusofnu.is/gogn/unu-gtp-report/UNUGTP-1898--10 (accessed on 28 December 2020).

78. Besser, H.; Mokadem, N.; Redhaounia, B.; Hadji, R.; Hamad, A.; Hamed, Y. Groundwater mixing and geochemical assessment of low-enthalpy resources in the geothermal field of southwestern Tunisia. Eur. Mediter. J. Environ. Integ. 2018, 3, 1-15. [CrossRef]

79. Kiełczawa, B.; Liber-Makowska, E.; Blachowski, J. Lądek-Zdrój study case. In Geothermal Energy-A Basis for Low-Emission Space Heating, Improving Living Conditions and Sustainable Development Preliminary Studies for Selected Areas in Poland, 1st ed.; Kępińska, B., Barbacki, A.P., Eds.; Study Visits' Report; IGSMiE, PAN: Kraków, Poland, 2017; pp. 224-261.

80. Fournier, R.O.; Potter, R.W. A Magnesium Correction for the Na-K-Ca Chemical Geothermometer; Report 78-986; U.S. Geological Survey: Menlo Park, California, CA, USA, 1979. Available online: http://pubs.usgs.gov/of/1978/098/report (accessed on 12 November 2020).

81. Dowgiałło, J. The Sudetic geothermal region of Poland. Geothermics 2002, 31, 343-359. [CrossRef]

82. Reed, M.H.; Spycher, N. Calculation of $\mathrm{pH}$ and mineral equilibria in hydrothermal waters with application to geothermometry and studies of boiling and dilution. Geochim. Cosmochim. Acta 1984, 48, 1479-1492. [CrossRef]

83. Zhang, X.; Guo, Q.; Li, J.; Liu, M.; Wang, Y.; Yang, Y. Estiamtion of reservoir temperature using silica and cationic solute geothermometers:a case study in the Tengchong geothermal area. Chin. J. Geochem. 2015, 34, 233-240. [CrossRef]

84. Barbacki, A.P.; Bujakowski, W.; Hajto, M.; Kępińska, B.; Kiełczawa, B.; Liber-Makowska, E.; Sapińska-Śliwa, A.; Sowiżdżał, A.; Stefaniuk, M.; Śliwa, T. Energia Geotermalna-Możliwości dla Niskoemisyjnego Ciepłownictwa, Poprawy Warunków Życia $i$ Zrównoważonego Rozwoju w Wybranych Obszarach Polski, 1st ed.; Wydawnictwa AGH: Kraków, Poland, 2017 ; pp. 5-74.

85. Szczepański, J. Proweniencja i Ewolucja Tektonometamorficzna Serii Suprakrustalnej w Krystaliniku Gór Bytrzyckich, 1st ed.; Wrocławska Drukarnia Naukowa PAN: Wrocław, Poland, 2010; p. 166.

86. Redlińska-Marczyńska, A. Gierałtów versus Śnieżnik gneisses-what is the real difference? Geologos 2011, 17, 71-96. [CrossRef]

87. Edmunds, M.; Smedley, P. Fluoride in natural waters. In Essentials of Medical Geology, Impacts of the Natural Environment on Public Health, 1st ed.; Sellinus, O., Alloway, B.J., Eds.; Elsevier Academic Press: New York, NY, USA, 2005; pp. $301-329$.

88. Polański, A.; Smulikowski, K. Geochemia, 1st ed.; Wydawnictwo Geologiczne: Warszawa, Poland, $1969 ;$ p. 662.

89. Appelo, C.A.J.; Postma, D. Geochemistry Groundwater and Pollution, 2nd ed.; Balcema Publisher: Leiden, The Netherlands, 2007; pp. 119-132.

90. Gierwielaniec, J.; Szarszewska, Z. Lądek-Zdrój (Lądek springs). In Proceedings of the Conference Hydrogeochemistry of Mineralized Waters, Cieplice Spa, Poland, 31 May-3 June 1978; pp. 371-373. 
91. Wise, W.S. Zeolites. In Encyclopedia of Geology, 1st ed.; Selley, R.C., Cocks, L.R.M., Eds.; Elsevier Academic Press: Oxford, UK, 2005; Volume 3, pp. 591-600.

92. Dowgiałło, J. Stan rozpoznania zasobów wód termalnych Region Sudeckiego i perspektywy ich wykorzystania. Tech. Posz. Geol. Geoterm. Zrównoważony Rozwój 2007, 46, 29-34. 